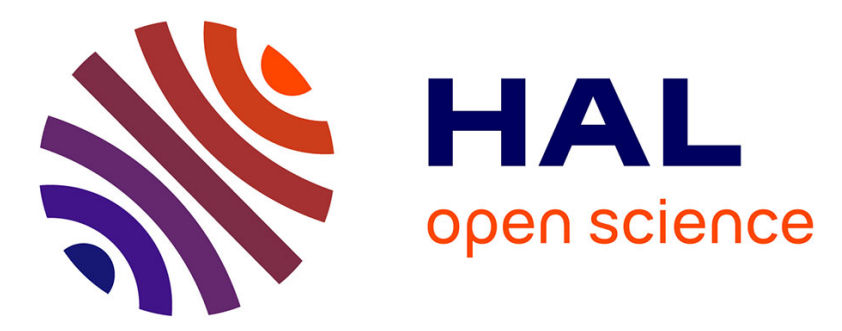

\title{
Impact of wastewater treatment plants on receiving surface waters and a tentative risk evaluation: the case of estrogens and beta blockers
}

\author{
V. Gabet Giraud, Cecile Miege, R. Jacquet, Marina Coquery
}

\section{- To cite this version:}

V. Gabet Giraud, Cecile Miege, R. Jacquet, Marina Coquery. Impact of wastewater treatment plants on receiving surface waters and a tentative risk evaluation: the case of estrogens and beta blockers. Environmental Science and Pollution Research, 2014, 21 (3), p. 1708 - p. 1722. 10.1007/s11356-0132037-7 . hal-01072988

\author{
HAL Id: hal-01072988 \\ https://hal.science/hal-01072988
}

Submitted on 8 Oct 2014

HAL is a multi-disciplinary open access archive for the deposit and dissemination of scientific research documents, whether they are published or not. The documents may come from teaching and research institutions in France or abroad, or from public or private research centers.
L'archive ouverte pluridisciplinaire HAL, est destinée au dépôt et à la diffusion de documents scientifiques de niveau recherche, publiés ou non, émanant des établissements d'enseignement et de recherche français ou étrangers, des laboratoires publics ou privés. 


\title{
Impact of wastewater treatment plants on receiving surface waters and a
}

\section{tentative risk evaluation: the case of estrogens and betablockers}

\author{
V. Gabet-Giraud, C. Miège*, R. Jacquet, M. Coquery
}

Irstea, U.R. MALY, 5 rue de la Doua, CS70077, 69626 Villeurbanne Cedex, France

*: corresponding author, cecile.miege@irstea.fr

\begin{abstract}
Five estrogenic hormones (unconjugated + conjugated fractions) and 10 betablockers were analyzed in three wastewater treatment plant (WWTP) effluents and receiving river waters in the area of Lyon, France. In the different samples, only two estrogens were quantified: estrone and estriol. Some betablockers, such as atenolol, acebutolol and sotalol, were almost always quantified, but others, e.g. betaxolol, nadolol and oxprenolol were rarely quantified. Concentrations measured in river waters were in the $\mathrm{ng} / \mathrm{L}$ range for estrogens and between 0.3 and $210 \mathrm{ng} / \mathrm{L}$ for betablockers, depending on the substance and the distance from the WWTP outfall. The impact of the WWTP on the receiving rivers was studied, and showed a clear increase in concentrations near the WWTP outfall. For estrogens, the persistence in surface waters was not evaluated given the low concentrations levels (around $1 \mathrm{ng} / \mathrm{L}$ ). For betablockers, concentrations measured downstream of the WWTP outfall were up to 16 times higher than those measured upstream. Also, the persistence of metoprolol, nadolol and propranolol was noted even $2 \mathrm{~km}$ downstream of the WWTP outfall. The comparison of betablocker fingerprints in the samples collected in effluent and in the river also showed the impact of WWTP outfall on surface waters. Finally, a tentative environmental risk evaluation was performed on 15 sites by calculating the ratio of receiving water concentrations to predicted non-effect concentrations (PNEC). For estrogens, a total PNEC of 5 ng/L was considered, and these substances were not linked to any potential environmental risk
\end{abstract}


(only one site showed an environmental risk ratio above 1). Unfortunately, few PNECs are available, and risk evaluation was only possible for 4 of the 10 betablockers studied: acebutolol, atenolol, metoprolol and propranolol. Only propranolol presented a ratio near or above 1, showing a possible environmental risk for 4 receiving waters out of 15 .

Keywords: estrogens, betablockers, wastewater treatment plant, surface water, risk evaluation

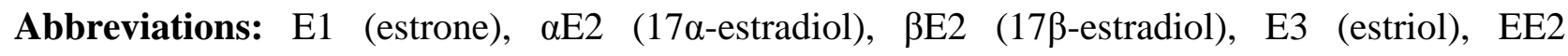
(ethynylestradiol), E1-D4 (estrone-D4), E2-D2 (17ß-estradiol-D2), E3-D2 (estriol-D2), EE2-D4 (17 $\alpha$-ethynylestradiol-D4), Eff. (effluent), SW (surface water), WWTP (wastewater treatment plant), ACE (acebutolol), ATE (atenolol), BET (betaxolol), BIS (bisoprolol), MET (metoprolol), NAD (nadolol), OXP (oxprenolol), PROP (propranolol), SOT (sotalol), TIM (timolol), ATE-D7 (atenolol-D7), MET-D7 (metoprolol-D7), PROP-D7 (propranolol-D7), MEC (measured environmental concentration), PNEC (predicted non-effect concentration), LC-MS/MS (liquid chromatography coupled with tandem mass spectrometry), MRM (multiple reaction monitoring), PEC (predicted environmental concentration), QMNA5 (5-year lowest water flow discharge), NOEC (chronic non-observed effect concentration), EC50 (half maximal effective concentration)

\section{Introduction}

Pharmaceuticals have been quantified worldwide at the ng/L level in surface waters (Grujic et al., 2009; Kasprzyk-Hordern et al., 2009; Zhou et al., 2009). Wastewater treatment plants (WWTPs) are recognized as the main entryway of these substances into the aquatic environment (Bendz et al., 2005; Castiglioni et al., 2006; Nakada et al., 2006). WWTPs are not designed to treat and remove pharmaceuticals, which are only degraded to some degree during sewage 
treatment (Miege et al., 2009b). Betablockers are a class of drugs used for various indications such as cardiac arrhythmias, hypertension and cardioprotection after a heart attack. These pharmaceuticals are widely used in France, where, for example, more than $18 \mathrm{t}$ of atenolol were consumed in 2004 (Besse et al., 2008). Once consumed, betablockers are excreted partly unchanged (Vieno et al., 2006; Hernando et al., 2007; Maurer et al., 2007). The consequences of their presence in the aquatic environment are not well-documented but the problem arised since beta-adrenergic receptors were found in fish (Haider and Baqri, 2000). Also, growth dysfunctions were observed on invertebrates in the presence of $0.5 \mathrm{mg} / \mathrm{L}$ of propranolol (Huggett et al., 2002). Unlike betablockers, estrogens can have a natural origin and are secreted daily by the human body (Ternes and Joss, 2006). They can also be consumed to treat, for example, menopausal problems or for contraception. In Europe, EE2, a synthetic estrogen, is commonly used in contraceptive pills: in 2004 in France, $40 \mathrm{~kg}$ of EE2 was consumed (Besse et al., 2008). These substances act as endocrine-disrupting compounds and can induce effects on fish reproduction from the $\mathrm{ng} / \mathrm{L}$ level (Hansen et al., 1998; Larsson et al., 1999; Jobling et al., 2003; Gutjahr-Gobell et al., 2006).

Betablockers in WWTP effluents and surface waters have already been studied (Ternes, 1998; Andreozzi et al., 2003; Gros et al., 2006; Miege et al., 2006; Vieno et al., 2006), but most of the analytical methods used are multi-residue methods (i.e. with a lower sensitivity) and only aimed at analyzing 4 or 5 betablockers. In France, few data for concentrations in rivers are available (Andreozzi et al., 2003; Miege et al., 2006; Coetsier et al., 2009) and to our knowledge, no data are available for atenolol, nadolol and sotalol, which are among the most hydrophilic betablockers, and widely used in France. Many studies have focused on estrogens and their analysis in effluents and surface waters (Baronti et al., 2000; Kuch and Ballschmiter, 2001; Lagana et al., 2004; Vethaak et al., 2005; Morteani et al., 2006; Vigano et al., 2006; Loos et al., 2007; Kuster et al., 2008), but few have been conducted in France (Cargouet et al., 2004; Labadie and Budzinski, 2005; Vulliet et al., 2008; Miege et al., 2009c). Although some estrogens are often 
analyzed (such as E1, $\beta E 2$ and EE2), others, such as $\alpha E 2$ and E3 are less frequently studied. Labadie et al. (2005) studied the impact of a WWTP on its receiving river by analyzing estrogens. Samples were collected from $30 \mathrm{~m}$ to $10 \mathrm{~km}$ downstream of a WWTP outfall, and the work focused on temporal and spatial steroid distributions along the river. Also, Castiglioni et al. (2006) studied the distribution and fate of pharmaceuticals (including atenolol, estrone, 17 $\beta$-estradiol and ethynylestradiol) in surface water receiving effluents from a WWTP; percentage attenuation in river water was also evaluated. However, these studies focused only on one site. In addition, Vieno et al. (2006) studied phamaceuticals in two rivers impacted by a WWTP, but only 4 betablockers were analyzed (acebutolol, atenolol, metoprolol and sotalol). The authors compared concentrations at different sampling points in the river and estimated loss of the compounds by comparing the load in the downstream river with the loads from all the WWTPs located on the river. Finally, Miege et al. (2009) proposed a risk evaluation study on 5 rivers impacted by effluent release. However, the study was based only on predictive environmental concentrations in rivers calculated from measured concentrations in effluent. Hence further investigations are needed to improve our knowledge of the extent of river contamination caused by WWTP outfall, which may vary according to the geographical location or the type of WWTP.

The objective of this study was to evaluate the impact of selected French WWTPs on the receiving waters. We analysed 10 betablockers: acebutolol (ACE), atenolol (ATE), betaxolol (BET), bisoprolol (BIS), metoprolol (MET), nadolol (NAD), oxprenolol (OXP), propranolol (PROP), sotalol (SOT) and timolol (TIM), and 5 estrogens: estrone (E1), 17 $\alpha$-estradiol $(\alpha \mathrm{E} 2), 17 \beta-$ estradiol ( $\beta E 2)$, estriol (E3) and ethynylestradiol (EE2) selected for their high consumption, the data available in the scientific literature or their toxicity. To evaluate the impact of WWTPs on receiving rivers, three sites located in the Lyon area were studied and both effluent and river samples were analyzed. For each site, concentrations measured in rivers upstream and downstream of the WWTP outfalls were compared. A tentative risk evaluation was performed for these three 
sites, using either measured concentrations in rivers or predicted concentrations in rivers from measured concentration in effluents. This tentative risk evaluation was completed using results obtained on 12 WWTP effluents previously analysed (Gabet-Giraud et al, 2010), and after calculation of predicted concentrations in downstream rivers.

\section{Materials and methods}

\subsection{Sampling}

To study the impact of wastewater treatment plants (WWTPs) on surface waters, river water and effluent samples were collected at three sites (Beaujeu, Bourgoin-Jallieu and Fontainessur-Saône, Figure 1). Automatic 24 h composite samples were collected for effluent according to Gabet-Giraud et al (2010). Grab surface water samples were collected in $2.5 \mathrm{~L}$ amber glass bottles previously rinsed twice with the sample water. All the samples were stored at $4{ }^{\circ} \mathrm{C}$ during transport to the laboratory. Filtering and extractions were performed within $24 \mathrm{~h}$ after sampling.

Three rivers located in the area of Lyon (France) were selected for this study (Figure 1). The River Saône (length 480 km) is the main tributary of the River Rhône. The sampling site, near Fontaines-sur-Saône, is impacted by domestic and industrial contaminations. The River Ardières (length $9.9 \mathrm{~km}$ ) is a tributary of the River Saône. The site, near the town of Beaujeu, is impacted by different contamination sources: wastewater treatment plants, industry and agriculture (mainly vineyards). The River Bourbre (length $72.2 \mathrm{~km}$ ) is another tributary of the River Rhône. This site, near the town of Bourgoin-Jallieu, is impacted by domestic and industrial contamination.

\section{Figure 1.}

The characteristics of the WWTPs studied are presented in Table 1. Two are equipped with a primary treatment system (primary settling). Biological treatments consist of activated sludge (conventional or medium rate) or a biological filter.

\section{Table 1.}


To study the impact of WWTPs, samples were collected in effluents and in rivers up- and downstream of the effluent outfall, as described in Table 1. For the River Bourbre a more complex configuration required a different sampling methodology (Figure 2). The River Bourbre was sampled at one sampling point located $20 \mathrm{~m}$ upstream, and two sampling points located $5 \mathrm{~m}$ and $2000 \mathrm{~m}$ downstream of the confluence with the Bion, which receives the WWTP effluent. The Bion was also sampled $2000 \mathrm{~m}$ upstream of the WWTP outfall.

To obtain representative results, sampling was performed once per week for at least three consecutive weeks. The Saône River was sampled on 6 different days in November 2007 and June 2008. The River Ardières was sampled 3 times in June 2008. The River Bourbre was sampled 4 times in September 2008. The Bion River samples are not considered in this paper (River Bion flow is negligible compared with the WWTP effluent flow). A total of 42 surface water samples (18 for Saône, 12 for Ardières and 12 for Bourbre) and 8 effluent samples (2 for Saône, 2 for Ardières and 4 for Bourbre) were collected between November 2007 and September 2008.

Figure 2.

\subsection{Sample preparation and analysis}

Water samples were first filtered through pyrolyzed $\left(450{ }^{\circ} \mathrm{C}, 1 \mathrm{~h}\right)$ glass fiber filters $(\mathrm{GF} / \mathrm{F}, 0.7 \mu \mathrm{m}$ pore size $)$.

The analytical method for the 5 estrogens is described elsewhere (Miege et al., 2009a). Briefly, aliquots of filtrate spiked with deuterated estrogens (E1-D4, E2-D2, E3-D2 and EE2-D4) were extracted by solid phase extraction (SPE) on Oasis HLB ${ }^{\circledR}$ cartridges and purified on Florisil cartridges. Extracts were evaporated to dryness and reconstituted in a solution of E2 acetate, used as an internal standard. For the analysis of total estrogens (i.e. after hydrolysis of conjugated forms), enzymatic cleavage was performed using $\beta$-glucuronidase isolated from Helix pomatia before extraction. 
The 10 betablockers were analysed as described in Gabet-Giraud et al (2010). Briefly, aliquots of acidified filtrate were extracted by SPE on Oasis $\mathrm{MCX}^{\circledR}$ cartridges, evaporated to dryness and reconstituted in a solution of metoprolol impurity A, used as an internal standard. Aliquots of each sample were also spiked with the 10 betablockers to define recoveries for each type of sample (i.e. river or effluent).

Analysis of estrogens and betablockers was performed by liquid chromatography coupled with tandem mass spectrometry (LC-MS/MS) with acquisition in multiple reaction monitoring (MRM) mode. As recommended in the EU Commission Decision 2002/657/EC, the MS-MS conditions included the use of two ionization transitions for each compound (except for the deuterated surrogates), one for quantification and one for identity confirmation.

Final estrogen concentrations were calculated using recoveries obtained for the internal deuterated surrogates ( $\alpha \mathrm{E} 2$ and $\beta \mathrm{E} 2$ were both corrected by E2D2). For betablockers, final concentrations were calculated using recoveries obtained for the non-deuterated betablockers in spiked samples: concentrations were corrected only if the recoveries were below $80 \%$ or above $120 \%$.

Method limit of quantification (LOQ) was estimated for each substance/sample pair as described elsewhere (Miege et al., 2009a). For E1, $\alpha \mathrm{E} 2, \beta \mathrm{E} 2$ and E3, LOQ values ranged between 0.3 and $2.7 \mathrm{ng} / \mathrm{L}$, it can reached $9.0 \mathrm{ng} / \mathrm{L}$ for EE2. For betablockers, LOQ ranged between 0.2 and $1.1 \mathrm{ng} / \mathrm{L}$

\subsection{Environmental risk evaluation}

To evaluate the potential impact of each substance on the aquatic environment, we determined a quotient risk calculated as the ratio of a measured environmental concentration (MEC) to a predicted non-effect concentration (PNEC). When MEC is not available, a predicted 
environmental concentration (PEC) can be used (European Commission, 2003). An ecological risk is suspected when the ratio (MEC or PEC)/PNEC equals or exceeds 1 for a given substance.

A tentative risk evaluation was compared using either the MEC or the PEC obtained in the three rivers studied (part 3.5). This tentative risk evaluation was completed (part 3.6) for receiving rivers of 12 WWTPs located in France (Paris area, Lyon area and in the south of France) using the PEC in rivers calculated from mean concentrations $(n=2$ or 3$)$ measured in effluent samples (AMPERES project, Gabet-Giraud et al., 2010).

For PEC calculation, fluxes of micropollutants were calculated (from concentrations measured in effluents and WWTP flow) and divided by the 5-year lowest water flow discharges of the receiving river (European Commission, 2003).

The 15 WWTPs (including the three studied in this paper) have various capacities (between 2900 and 700,000 PE) and discharge their effluents into rivers of different sizes (from 0.02 to 600 $\left.\mathrm{m}^{3} / \mathrm{s}\right)$

\section{Results and discussion}

\subsection{Occurrence of estrogens}

The frequency of quantification and measured concentrations are presented in Table 2. Three estrogens ( $\alpha \mathrm{E} 2, \beta E 2$ and EE2) were never quantified in effluents or in surface waters. The most frequently quantified estrogen was E1, present in all the effluent samples and in $98 \%$ of surface water samples. Concentrations of E1 ranged from 1.7 to $20 \mathrm{ng} / \mathrm{L}$ (mean $1.6 \mathrm{ng} / \mathrm{L}$ ) in effluent samples and from 0.3 to $3.9 \mathrm{ng} / \mathrm{L}$ (mean $9.3 \mathrm{ng} / \mathrm{L}$ ) in surface waters. Also, E1 is one of the estrogen present at the highest concentrations in influent samples (Gabet-Giraud et al., 2010); it is produced by biodegradation of $\beta E 2$ and EE2 (Ternes et al., 1999a; Czajka and Londry, 2006; Ren et al., 2007). E3 was quantified only in the effluent samples from Fontaines-sur-Saône WWTP, and in 1 of the 9 samples collected in the River Saône downstream of the WWTP. The measured 
concentrations in the effluent samples were high (between 202 and $218 \mathrm{ng} / \mathrm{L}$ ), but decreased to $26 \mathrm{ng} / \mathrm{L}$ in surface waters downstream from the WWTP.

In the literature, as here, $\alpha \mathrm{E} 2, \beta \mathrm{E} 2$ and EE2 have not been quantified in effluent or in surface water (Boyd et al., 2003; Rodriguez-Mozaz et al., 2004; Labadie and Budzinski, 2005; Farre et al., 2006; Kuster et al., 2008; Vulliet et al., 2008). A recent review (Miege et al., 2009b) showed that E1 was quantified in 93\% of the effluent samples studied ( $n=79)$, at concentrations ranging between 0.6 and $95 \mathrm{ng} / \mathrm{L}$ (mean value $20.9 \mathrm{ng} / \mathrm{L}$ ), in agreement with our results. This review also showed that E3 was quantified in more than $90 \%$ of the effluent samples $(n=33)$; that is in the range of the maximum values reported in our study. Results from the literature confirmed a low quantification frequency of E3 in surface waters (Rodriguez-Mozaz et al., 2004; Labadie and Budzinski, 2005; Farre et al., 2006; Kuster et al., 2008). Reported concentrations of E3 in surface waters ranged from 1 to $50 \mathrm{ng} / \mathrm{L}$ (Morteani et al., 2006; Vigano et al., 2006; Kuster et al., 2008; Peng et al., 2008). A study conducted on the Mississippi River in the United States (a site outside the direct influence of discharge points from WWTPs) and on Lake Pontchartrain (Louisiana USA), showed that E1 was never detected $(n=4, \mathrm{LOD}=0.3 \mathrm{ng} / \mathrm{L})$ (Boyd et al., 2003). In a recent survey conducted on several European rivers, including the Rivers Ardières and Bourbre, a quantification frequency of $16 \%$ was reported for E1 $(n=122$, average concentration of $4 \mathrm{ng} / \mathrm{L})$ (Loos et al., 2009); E1 was quantified at $3 \mathrm{ng} / \mathrm{L}$ in the River Bourbre, but was not quantified in the River Ardières. However, in this study the LOD was relatively high for E1 (2 ng/L). By contrast, in a study conducted in Italy in the Rivers Po and Lambro, E1 was quantified in all samples $(n=3)$ between 4 and $47 \mathrm{ng} / \mathrm{L}$ (Vigano et al., 2006); E3 was also quantified in all samples $(n=3)$ at concentrations ranging between 4 and $50 \mathrm{ng} / \mathrm{L}$. In samples collected in the River Tamagawa and Lake Kasumigaura (Japan) receiving WWTP outfall, E1 was quantified systematically at concentrations between 0.2 and $3.8 \mathrm{ng} / \mathrm{L}(n=8)$ and E3 was never detected (LOD of $1.5 \mathrm{ng} / \mathrm{L})$ (Isobe et al., 2003). In France, a study conducted on an urban dam (receiving effluents from 
various WWTPs and industrial effluents) and a lake (supplied by different rivers from rural zones) in the Rhône-Alpes area, showed that E1 was only quantified in one lake sample at $0.3 \mathrm{ng} / \mathrm{L}$ (Vulliet et al., 2008). E1 was never detected in the River Seine, between 200 and $355 \mathrm{~km}$ downstream of the city of Paris $(n=6$, LOD between 0.3 and $8.0 \mathrm{ng} / \mathrm{L}$ depending on the analyte and the matrix) (Labadie and Budzinski, 2005), while it was quantified from 1.1 to $3.0 \mathrm{ng} / \mathrm{L}$ in all samples $(n=6)$ collected in the Rivers Seine and Oise upstream and downstream (about $60 \mathrm{~km})$ of Paris (Cargouet et al., 2004). However, some studies reported higher concentrations: up to $65 \mathrm{ng} / \mathrm{L}$ in a Chinese river located in one of the most developed and densely populated areas of China (Peng et al., 2008).

The differences between total (i.e. conjugated + unconjugated fractions) and unconjugated fractions of estrogens were not significant. The proportion of free (i.e. unconjugated) estrogens represented on average about $80 \%$ of the total estrogens for effluent and surface waters. The differences between estrogen concentrations measured in samples with and without hydrolysis could be linked to the analytical uncertainty, which was estimated in the range $20-50 \%$ depending on the measured concentration. Thus we can consider that most of the estrogens in surface water and effluent samples are present in the free form. Comparable results were obtained in surface water samples (Belfroid et al., 1999). Estrogens are excreted by bodies in conjugated forms (glucuronide or sulfate) which are more soluble, but in activated sludge processes, cleavage (E1-3S in E1, and E2-17G in $\beta E 2$ ) was observed (Ternes et al., 1999b; Baronti et al., 2000).

\section{Table 2}

\subsection{Occurrence of betablockers}

Betablockers were analyzed in 8 effluents and 34 surface water samples (Table 2); they were not measured in the River Saône sampled in June 2008. 
In effluent samples, ACE, ATE, BIS, MET, PROP and SOT were always quantified. The other betablockers, TIM, NAD, OXP and BET were quantified in $88,50,38$ and $25 \%$ of effluent samples, respectively. The highest concentrations were observed for ATE, SOT, ACE and PROP, with median concentrations above $138 \mathrm{ng} / \mathrm{L}$. Median concentrations were lower than $50 \mathrm{ng} / \mathrm{L}$ for NAD, MET, BIS and OXP, with only traces of TIM.

In surface waters, ACE, ATE and SOT were the most frequently quantified betablockers (>90\%), while NAD, BET and OXP were only quantified in fewer than $32 \%$ of the samples. BIS, MET, PROP and TIM were quantified at intermediate frequencies (44-82\%) in surface water samples, respectively. ATE, ACE and SOT were present at the highest median concentrations: 17, 14 and $5.5 \mathrm{ng} / \mathrm{L}$, respectively. Median concentrations ranged between 0.3 and $4.6 \mathrm{ng} / \mathrm{L}$ for other betablockers.

In the literature, ACE, ATE, BIS, MET, PROP and SOT are generally quantified in effluent samples (>86\%) with mean concentrations ranging between 10 and $990 \mathrm{ng} / \mathrm{L}$ (Andreozzi et al., 2003; Vieno et al., 2006; Miege et al., 2009b). Reported concentrations for a substance can vary widely from one country to another. For example, while MET was quantified at $80 \mathrm{ng} / \mathrm{L}(n=2)$ in France (Andreozzi et al., 2003), concentrations between 910 and $1070 \mathrm{ng} / \mathrm{L}(n=3)$ were measured in Finland (Vieno et al., 2006). For NAD and OXP, reported detection frequencies were higher than those observed in our study. In a study conducted in the United States of America, NAD was quantified in $71 \%$ of the effluent samples $(n=34)$ at a median concentration of $51 \mathrm{ng} / \mathrm{L}$ (Huggett et al., 2003). Also, in a WWTP effluent monitoring campaign conducted in 4 European countries including France, OXP was quantified in $71 \%$ of the samples $(n=7$, median concentration 20 ng/L) (Andreozzi et al., 2003). On the contrary, while TIM was quantified in $88 \%$ of the effluent samples in our study (mean concentration of $3.6 \mathrm{ng} / \mathrm{L}$ ), it was only quantified in fewer than $7 \%$ of German effluents $(n=29)$; however, the LOQ in the German study was relatively high $(25 \mathrm{ng} / \mathrm{L})$ (Ternes, 1998). For BET, which was only quantified in $25 \%$ of the effluent samples, a previous 
study in 4 European countries including France reported concentrations below LOD (Andreozzi et al., 2003). However, the LOD were not detailed.

In surface water, various results have been reported. In a study conducted in the Rivers Po and Lambro, in the most densely inhabited and industrialized areas of Italy, ATE was quantified in all river samples $(n=8)$ between 3.4 and $241 \mathrm{ng} / \mathrm{L}$ (Calamari et al., 2003). By contrast, ATE was quantified only in $60 \%$ of the samples collected in the River Vantaa, located in the most densely populated area of Finland, at concentrations between 12 and $25 \mathrm{ng} / \mathrm{L}$ (Vieno et al., 2006); the same study reported a quantification frequency of $80 \%(n=5)$ for ACE, SOT and MET, with concentrations between 2 and $8 \mathrm{ng} / \mathrm{L}, 15$ and $52 \mathrm{ng} / \mathrm{L}$ and 20 and $116 \mathrm{ng} / \mathrm{L}$, respectively. Conversely, a study performed in the River Seine in the Paris area quantified MET in only $30 \%$ of the collected samples $(n=10)$ at a mean concentration of $10 \mathrm{ng} / \mathrm{L}$ (Paffoni et al., 2006); ATE, SOT, PROP and BIS were also analyzed $(n=10$, quantification frequency of $100 \%, 100 \%, 50 \%$ and 0 , respectively) and measured with mean concentrations of $26,45,12 \mathrm{ng} / \mathrm{L}$ and $<10 \mathrm{ng} / \mathrm{L}$, respectively. For PROP, the same quantification frequency $(50 \%, n=6)$ was observed in a study conducted in the Rivers Taff (UK) and Warta (Poland) with measured concentrations between 5 and $6 \mathrm{ng} / \mathrm{L}$ (Kasprzyk-Hordem et al., 2007); ATE and MET were also found between 3 and $60 \mathrm{ng} / \mathrm{L}$, and 7 and $155 \mathrm{ng} / \mathrm{L}$, respectively (quantification frequency of $67 \%$ and 50\%, respectively). In surface water collected in Spain in the Ebro river basin, MET and PROP were not detected ( $n=10$, LOD of 3 and 2, respectively) and SOT and ATE were quantified at up to 70 and 250 ng/L, respectively (Gros et al., 2006). Generally, reported concentrations of BIS, BET, NAD, MET, PROP and TIM are below 10 ng/L (Ternes, 1998; Gros et al., 2006; Paffoni et al., 2006). However, concentrations measured in surface water can reach high values: BIS and MET were quantified at above $2000 \mathrm{ng} / \mathrm{L}$ in river water samples (Ternes, 1998).

\subsection{Qualitative impact of WWTPs on surface waters}


Generally, among the three sites studied, the River Bourbre was the one where the impact of the WWTP outfall was the most obvious (Figure 3, Supplementary material). The WWTP outfall was the least diluted for this river: the average dilution factor (calculated as the ratio River flow / WWTP flow) was 14, against 70 and 7000 for the Rivers Ardières and Saône, respectively.

\section{Figure 3}

For estrogens, because of the relatively low concentrations measured in effluent samples, the impact of WWTPs in surface water was not significant; except in the River Bourbre, where the high concentration of $\mathrm{E} 1$ in the effluent (maximum of $16 \mathrm{ng} / \mathrm{L}$ ) lead to a slight increase in E1 concentration in the river (from 1.6 to $2.5 \mathrm{ng} / \mathrm{L}$, on average) immediately downstream from the WWTP. However, $2 \mathrm{~km}$ after the outfall of the WWTP (sampling point "Downstream 2"), concentrations of E1 were equivalent to those measured upstream. E3 was only quantified in effluent samples of Fontaines-sur-Saône (average concentration $210 \mathrm{ng} / \mathrm{L}$ ) and in one sample collected downstream of the outfall (at $26 \mathrm{ng} / \mathrm{L}$ ). As only low concentrations of E1 and too few data for E3 were measured in river water, the profile study and also the quantitative study of the impact of WWTPs on downstream rivers (see below) were not conducted on these hormones.

For betablockers, the impact of WWTPs was also more visible in the River Bourbre. For example, the average concentration increased after the WWTP outfall from 14 to $99 \mathrm{ng} / \mathrm{L}$ for ACE, from 28 to $123 \mathrm{ng} / \mathrm{L}$ for ATE and from 8.4 to $120 \mathrm{ng} / \mathrm{L}$ for SOT. In the River Saône, the average concentration increased from 14 to $76 \mathrm{ng} / \mathrm{L}$ for ACE, from 10 to $93 \mathrm{ng} / \mathrm{L}$ for ATE and from 22 to $67 \mathrm{ng} / \mathrm{L}$ for SOT. For these two rivers, the increase in concentrations after the WWTP was also measurable for BIS, MET and PROP. In the River Ardières, average concentrations increased from 9.1 to $39 \mathrm{ng} / \mathrm{L}$ for $\mathrm{ACE}$ and from 2.2 to $29 \mathrm{ng} / \mathrm{L}$ for ATE after the WWTP outfall (for ATE, concentration of upstream 1 was considered because of the abnormally high concentration in upstream 2). However, in the River Ardières, the concentration of SOT from WWTP effluent did not lead to a significant increase of concentration in the river (from 3.5 to $5.2 \mathrm{ng} / \mathrm{L}$ ). 
To evaluate the impact of WWTP outfall on river water quality, we compared the profile of the 10 betablockers in effluent samples with those of river water upstream and downstream of the WWTP outfall. For each sampling point, the relative abundance of each substance was calculated by dividing its concentration by the sum of all betablocker concentrations. This study was only conducted on samples from the River Bourbre as this was the site where the WWTP impact was the most visible (Figure 4). The river water collected immediately after the WWTP outfall (Downstream 1) and the effluent had similar profiles, whereas the profile observed in river water collected upstream of the WWTP was different from the profile of the effluent sample. Moreover, the profiles of water samples collected upstream and downstream 2 were again similar, showing a return to upstream conditions $2 \mathrm{~km}$ downstream the WWTP outfall.

\section{Figure 4}

\subsection{Quantitative impact of WWTP on surface waters}

To evaluate quantitatively the observed gradient from upstream to downstream of the WWTP outfall, we calculated for betablockers a ratio of increase as follows:

$$
\text { Increase }=\frac{C_{\text {Downstream }}-C_{\text {Upstream }}}{C_{\text {Upstream }}},
$$

where $C_{\text {Downstream }}$ is the measured concentration in the river immediately downstream of the WWTP outfall, and $C_{\text {Upstream }}$ is the measured concentration in the river immediately upstream of the WWTP outfall.

When a significant increase was noted, an attenuation percentage was calculated as the difference in concentration between downstream 1 and downstream 2 as follows:

$$
\text { Attenuation }(\%)=\frac{\left(C_{\text {Downstream 1 }}-C_{\text {Upstream }}\right)-\left(C_{\text {Downstream 2 }}-C_{U p s t r e a m}\right)}{\left(C_{\text {Downstream 1 }}-C_{U \text { sstream }}\right)} \times 100,
$$


where $C_{\text {Downstream 1 }}$ is the measured concentration in the river immediately downstream of the WWTP outfall, and $C_{\text {Downstream } 2}$ is the measured concentration in the river at the second point downstream of the WWTP outfall.

As shown in Table 3, concentrations of betablockers in surface waters downstream of the WWTP outfall can be up to 13 times higher than concentrations measured upstream. Concerning the 4 substances quantified in effluents at the highest concentrations (ACE, ATE, SOT and PROP), concentrations increased by a factor of 3 to 13 in the River Bourbre, 0 to 12 in the River Ardières and 2 to 8 in the River Saône. Also, the impact of WWTP outfall was generally greater on the River Bourbre than on the Rivers Saône or Ardières (except for ATE) because of the lower effluent dilution for the River Bourbre. For example, MET, which was quantified at similar concentrations in effluent from Beaujeu and Bourgoin Jallieu WWTP (30-40 ng/L), showed a concentration 6 times higher in surface water after WWTP outfall in the River Bourbre, while no concentration variation was noted for the River Ardières. On the contrary, while ATE concentration was multiplied by 3 after WWTP outfall in the River Bourbre, it was, surprisingly, multiplied by 12 in the River Ardières; this result is linked to the high concentration of ATE measured upstream of the WWTP outfall in the River Bourbre (mean concentration $28 \mathrm{ng} / \mathrm{L}$ ). For NAD and TIM, which were quantified at low concentrations in all effluent samples $(<56 \mathrm{ng} / \mathrm{L})$, the impact of the WWTP outfall was not detected on river concentrations.

To study the fate and behavior of betablockers in the downstream rivers, the attenuation of concentration between samples collected immediately after the effluent outfall $(5 \mathrm{~m})$ and samples collected further downstream (2000 m for the River Bourbre and $20 \mathrm{~m}$ for the River Ardières) was evaluated. MET and PROP seemed to be the most persistent betablockers, since their attenuation was below $10 \%$ at Bourgoin. Higher attenuations of concentration were noted for ACE at both sites: around 54\%. Considering the low hydrophobicity of this substance (log Kow 1.42) (Detroyer et al., 2001), it is not likely to be adsorbed on particulate matter. The attenuation of ACE may 
therefore be explained by degradation occurring in river water even only $20 \mathrm{~m}$ downstream of the effluent outfall; likewise for SOT, which was half degraded after $20 \mathrm{~m}$. For ATE, while an attenuation of $61 \%$ was noted in the River Bourbre $(2000 \mathrm{~m})$, it was only $11 \%$ in the River Ardières $(20 \mathrm{~m}$ ) because of a lower degradation. We observed that BIS was $61 \%$ degraded after $2000 \mathrm{~m}$. No assertion is possible for NAD and TIM, because measurements were too close to the LOQ. The analysis of particulate matter content and of samples collected at several points downstream of the effluent outfall would give a better understanding of the behavior and fate of betablockers at these sites.

A study reported in the literature on several pharmaceuticals (including ATE) also evaluated the attenuation between measured concentrations along the River Olona (Italy), $100 \mathrm{~m}$ and $1000 \mathrm{~m}$ downstream a WWTP outfall (Castiglioni et al., 2006). It showed an attenuation of $29 \%$ for ATE. Surprisingly, ATE was also detected in particulate matter, but exact content could not be quantified. Another study focused on the fate and behavior of several pharmaceuticals, including ACE, ATE, MET and SOT, in the River Vantaa in Finland, downstream of several WWTP outfalls (Vieno et al., 2006): Results showed the persistence of ATE and SOT (loss $\leq$ $10 \%$ ) but a significant elimination of ACE and MET (loss > 60\%) along the river. The distance between the last WWTP and the sampling point in the river was much higher than in our study (above $10 \mathrm{~km}$ ).

Table 3

\subsection{Calculation of predicted environmental concentration (PEC) and comparison with measured concentration (MEC)}

To assess the representativity of PEC values, PECs in rivers (from effluent measurement) were compared with MECs in rivers (from river measurement, minimum and maximum values), for the three sites studied here (Table 4). For E1, PECs were generally found in the same range as 
MECs for the River Bourbre. In contrast, for the Rivers Saône and Ardières, PECs for E1 were systematically underestimated compared with MECs (i.e. PECs 20 to 100 times lower than MECs in the River Saône, 3 to 16 times lower in the River Ardières). These differences can be explained by the presence of other WWTPs upstream of the target WWTP that could contribute to the total amount of micropollutants in the river. Concerning E3, which was only quantified in effluents from one of the three sites studied, PECs were close to LOQ, and therefore it is difficult to draw any firm conclusion. For betablockers, in the Rivers Bourbre and Ardières, 77\% of PECs were higher than the corresponding MECs by a factor of 1.1 to 4 . Nonetheless, for these rivers, a reasonably fit could generally be noted between PEC and MEC. In contrast, PECs calculated for betablockers in the River Saône were generally underestimated, by a factor up to 30 for BIS. To conclude, the use of PEC is not completely reliable and, unexpectedly, it does not always represent the worst possible case; MEC values, when available, are to be preferred to PEC values.

\section{Table 4}

\subsection{Tentative risk evaluation for the rivers downstream of 15 French WWTPs}

To evaluate the environmental risk linked to the presence of estrogens and betablockers in French rivers, MECs for the three rivers studied here and PECs for the receiving rivers of the 12 WWTPs previously studied were compared for each substance with PNEC values found in the literature (Table 5).

The PNEC values were computed from toxicity tests, but are available only for some of the substances studied. For estrogens, a rough estimation of PNEC at $5 \mathrm{ng} / \mathrm{L}$ was made (StuerLauridsen et al., 2000). For betablockers, PNEC were available for only 4 of the 10 betablockers analyzed. One author estimated EC50 (half maximal effective concentration) for ATE, MET and PROP on different species: an invertebrate (Daphnia magna), an alga (Desmodesmus subspicatus) and an aquatic plant (Lemna minor). The PNECs were obtained by dividing the lowest EC50 by an 
assessment factor of 1000 (Cleuvers, 2005). The following results were obtained: PROP was the most toxic substance with a PNEC at $0.73 \mu \mathrm{g} / \mathrm{L}$; the PNECs of ATE and MET were evaluated at 7.9 and $310 \mu \mathrm{g} / \mathrm{L}$, respectively. Another study reported a PNEC derived from chronic tests on fish at $10 \mathrm{ng} / \mathrm{L}$ for PROP (Ferrari et al., 2004). For ACE, a PNEC was evaluated at $1250 \mu \mathrm{g} / \mathrm{L}$ on an invertebrate (Ceriodaphnia dubia) by dividing the lowest NOEC (chronic non-observed effect concentration) by 50 (Garric et al., 2006). No PNEC value was found for NAD, but the toxicity tests performed on aquatic invertebrates showed that acute exposure to NAD at $100 \mathrm{mg} / \mathrm{L}$ resulted in no change in species survival (Huggett et al., 2002). Thus the following PNECs were used for this environmental risk evaluation study: $5 \mathrm{ng} / \mathrm{L}$ for total estrogens ("total" meaning the sum of estrogens), $1250 \mu \mathrm{g} / \mathrm{L}$ for ACE, $7.9 \mu \mathrm{g} / \mathrm{L}$ for ATE, $310 \mu \mathrm{g} / \mathrm{L}$ for MET and $10 \mathrm{ng} / \mathrm{L}$ for PROP.

For estrogens, total risk evaluation ratios evaluated with MECs of the three rivers studied ranged between 0.3 and 5.5 (Table 5). The atypical ratio of 5.5 is linked to the high concentration of E3 measured in one of the samples collected in the River Saône (25.9 ng/L). Among the receiving rivers of the 12 additional WWTPs studied, total risk evaluation ratios never exceeded 0.8. This shows a generally low predicted environmental risk associated with these substances in the systems studied.

Concerning betablockers, for ACE, ATE and MET, the ratio between MEC (or PEC) and PNEC were in most cases below 0.2, showing an non-significant predicted environmental risk. For PROP, the mean ratios were $0.3,0.8$ and 1.7 for the Rivers Ardières, Saône and Bourbre, respectively (ratio between 0.1 and 0.7 for the River Ardières, between 0.3 and 2.5 for River Saône and between 0.8 and 3.5 for River Bourbre). For PROP, among the receiving rivers of the 15 WWTP effluents presented in Table 5, a ratio below 0.1 was calculated for 2 sites, while 8 sites showed a ratio between 0.1 and 1 , and 5 sites had a ratio higher than 1 and up to 34.2. These 5 sites correspond to the rivers where the WWTP effluents were the least diluted (Rivers Bourbre, Maurepas, Maldroit, Bouillide and Ardières). From Table 5, PROP may represent a potential 
environmental risk up to a dilution ratio of the effluent in the river of 13. A previous study performed on two large French rivers (the Saône and the Rhône) presented lower ratios PEC/PNEC for PROP: between 0.03 and 0.45 depending on the site studied (Miege et al., 2006). In the present study, the fluxes of PROP were in the same range as those observed by Miege et al. (2006) but the 5-year lowest water flow discharges were 100 times lower.

\section{Table 5}

\section{Conclusion}

Three different sites in the Lyon area of France, were studied, showing that among the 5 estrogens analyzed, only E1 and E3 were quantified in some effluents and river waters. The most frequently quantified estrogen was E1. The concentration of estrogen reached $220 \mathrm{ng} / \mathrm{L}$ in effluent (for E3) and $26 \mathrm{ng} / \mathrm{L}$ in river water (for E3). However, mean estrogen concentration in surface water was generally at the ng/L level. Among the 10 betablockers analyzed, ACE, ATE and SOT were quantified in almost all the collected samples. Other substances, such as BET, NAD and OXP, were rarely quantified. Betablocker concentrations could reach up to $2450 \mathrm{ng} / \mathrm{L}$ in effluent and $240 \mathrm{ng} / \mathrm{L}$ in surface water (for ATE), but mean concentrations of individual betablocker in river water were below $50 \mathrm{ng} / \mathrm{L}$.

The impact of WWTPs on the receiving rivers was manifest for all the sites studied, except for estrogens at Fontaines-sur-Saône, where the effluent was highly diluted in the river (dilution by nearly 7000). Concentrations of estrogens and betablockers generally increased downstream of the WWTP outfall; this was particularly the case on the River Bourbre, which was, among the different sites studied, the one where the effluent was the least diluted in the river. Downstream of the effluent outflow, the betablocker concentrations could be up to 13 times higher than upstream of the WWTP. The study of the attenuation of concentration between samples collected immediately after the effluent outfall $(5 \mathrm{~m})$ and samples collected further downstream (20 m or 2 
$\mathrm{km}$ ) showed that some betablockers, such as MET and PROP, were not degraded even $2 \mathrm{~km}$ after the WWTP outfall, whereas others, like ACE were mostly degraded (more than 50\% of attenuation). The similarity of the relative distribution (i.e. fingerprint) of the betablockers was shown between samples of effluent and river samples collected immediately downstream of the effluent outflow.

An environmental risk evaluation was performed on 15 sites (including the three studied here). For estrogens, the total risk evaluation ratios were systematically below 1, except for one site, thus the low predictive environmental risk was low. With a ratio below 0.1 , the predictive environmental risk linked to the presence of ATE, ACE and MET in river water was negligible. On the contrary, ratios above 1 were obtained for PROP, showing a possible environmental risk for 5 sites. Betablockers can represent a potential environmental risk up to a dilution ratio of the effluent in the river of 13. Unfortunately, as no PNEC was found for SOT, it was impossible to evaluate the risk linked to its presence in the aquatic environment, although we showed high concentrations in rivers. Even though potential toxicity due to individual betablocker or estrogen was not proved here, the environmental risk evaluation presented here did not take into account synergistic, antagonist or bioaccumulation effects.

\section{Acknowledgments}

We thank O. Geffard and R. Mons for sampling assistance, and P. Bados and S. Schiavone for analytical support. We also thank the Regional Water Agency of Rhône-Méditerranée-Corse and the National Research Agency (ANR Precodd AMPERES project) for financial support.

\section{References}

Andreozzi R, Raffaele M, Nicklas P (2003) Pharmaceuticals in STP effluents and their solar photodegradation in aquatic environment. Chemosphere. 50 (10): 1319-1330.

Baronti C, Curini R, D'Ascenzo G, Di Corcia A, Gentili A, Samperi R (2000) Monitoring natural and synthetic estrogens at activated sludge sewage treatment plants and in a receiving river water. Environ Sci Technol. 34 (24): 5059-5066. 
Belfroid AC, Van der Horst A, Vethaak AD, Schafer AJ, Rijs GBJ, Wegener J, Cofino WP (1999) Analysis and occurrence of estrogenic hormones and their glucuronides in surface water and waste water in The Netherlands. Science of the Total Environment. 225 (1-2): 101-108.

Bendz D, Paxeus NA, Ginn TR, Loge FJ (2005) Occurrence and fate of pharmaceutically active compounds in the environment, a case study: Hoje River in Sweden. Journal of Hazardous Materials. 122 (3): 195-204.

Besse JP, Kausch-Barreto C, Garric J (2008) Exposure assessment of pharmaceuticals and their metabolites in the aquatic environment: Application to the French situation and preliminary prioritization. Human and Ecological Risk Assessment. 14 (4): 665-695.

Boyd GR, Reemtsma H, Grimm DA, Mitra S (2003) Pharmaceuticals and personal care products (PPCPs) in surface and treated waters of Louisiana, USA and Ontario, Canada. Science of the Total Environment. 311 (1-3): 135-149.

Calamari D, Zuccato E, Castiglioni S, Bagnati R, Fanelli R (2003) Strategic survey of therapeutic drugs in the rivers Po and Lambro in northern Italy. Environ Sci Technol. 37 (7): 1241-1248.

Cargouet M, Perdiz D, Mouatassim-Souali A, Tamisier-Karolak S, Levi Y (2004) Assessment of river contamination by estrogenic compounds in Paris area (France). Science of the Total Environment. 324 (13): 55-66.

Castiglioni S, Bagnati R, Fanelli R, Pomati F, Calamari D, Zuccato E (2006) Removal of pharmaceuticals in sewage treatment plants in Italy. Environ Sci Technol. 40 (1): 357-363.

Cleuvers M (2005) Initial risk assessment for three beta-blockers found in the aquatic environment. Chemosphere. 59 (2): 199-205.

Coetsier CM, Spinelli S, Lin L, Roig B, Touraud E (2009) Discharge of pharmaceutical products (PPs) through a conventional biological sewage treatment plant: MECs vs PECs? Environment International. 35 (5): 787-792.

Czajka CP, Londry KL (2006) Anaerobic biotransformation of estrogens. Science of the Total Environment. 367 (2-3): 932-941.

Detroyer A, Heyden YV, Carda-Broch S, Garcia-Alvarez-Coque MC, Massart DL (2001) Quantitative structure-retention and retention-activity relationships of beta-blocking agents by micellar liquid chromatography. J Chromatogr A. 912 (2): 211-221.

European Commission, EU Commission Decision of 12 August 2002 implementing Council Directive 96/23/EC concerning the performance of analytical methods and the interpretation of results (2002/657/EC), Offic. J. Eur. Commun. L221 (2002) 8.

European Commission JRC (2003) Technical Guidance Document in support of Commission Directive 93/67/EEC on Risk Assessment for new notified substances, Commission Regulation (EC) No 1488/94 on Risk Assessment for existing substances, Directives 98/8/EC of the European Parliament and of the Council concerning the placing of biocidal products on the market, Part II Environmental Risk Assessment - Office for official publications of the European Communities, Luxembourg.

Farre M, Brix R, Kuster M, Rubio F, Goda Y, de Alda MJL, Barcelo D (2006) Evaluation of commercial immunoassays for the detection of estrogens in water by comparison with high-performance liquid chromatography tandem mass spectrometry HPLC-MS/MS (QqQ). Anal Bioanal Chem. 385 (6): 10011011.

Ferrari B, Mons R, Vollat B, Fraysse B, Paxeus N, Lo Giudice R, Pollio A, Garric J (2004) Environmental risk assessment of six human pharmaceuticals: Are the current environmental risk assessment procedures sufficient for the protection of the aquatic environment? Environ Toxicol Chem. 23 (5): 1344-1354.

Gabet-Giraud V, Miege C, Choubert JM, Martin Ruel S, Coquery M (2010) Analysis of estrogens and beta blockers in the dissolved phase of wastewater treatment plants in France. Science of the Total Environment. 408: 4257-4269

Garric J, Ferrari B, Fraysse B, Mons R, Vollat B (2006) Effects of some human pharmaceutical on freshwater organisms (Impact de médicaments à usage humain sur les organismes aquatiques d'eau douce). Environnement, Risques et Santé. 5 (4): 290-295.

Gros M, Petrovic M, Barcelo D (2006) Development of a multi-residue analytical methodology based on liquid chromatography-tandem mass spectrometry (LC-MS/MS) for screening and trace level determination of pharmaceuticals in surface and wastewaters. Talanta. 70 (4): 678-690.

Grujic S, Vasiljevic T, Lausevic M (2009) Determination of multiple pharmaceutical classes in surface and ground waters by liquid chromatography-ion trap-tandem mass spectrometry. J Chromatogr A. 1216 (25): 4989-5000. 
Gutjahr-Gobell RE, Zaroogian GE, Horowitz DJB, Gleason TR, Mills LJ (2006) Individual effects of estrogens on a marine fish, Cunner (Tautogolabrus adspersus), extrapolated to the population level. Ecotox Environ Safe. 63 (2): 244-252.

Haider S, Baqri SSR (2000) beta-Adrenoceptor antagonists reinitiate meiotic maturation in Clarias batrachus oocytes. Comparative Biochemistry and Physiology a-Molecular \& Integrative Physiology. 126 (4): 517-525.

Hansen PD, Dizer H, Hock B, Marx A, Sherry J, McMaster M, Blaise C (1998) Vitellogenin - a biomarker for endocrine disruptors. Trends Analyt Chem. 17 (7): 448-451.

Hernando MD, Gomez MJ, Aguera A, Fernandez-Alba AR (2007) LC-MS analysis of basic pharmaceuticals (beta-blockers and anti-ulcer agents) in wastewater and surface water. Trends Anal. Chem. 26 (6): 581-594.

Huggett DB, Brooks BW, Peterson B, Foran CM, Schlenk D (2002) Toxicity of select beta adrenergic receptor-blocking pharmaceuticals (B-blockers) on aquatic organisms. Archives of Environmental Contamination and Toxicology. 43 (2): 229-235.

Huggett DB, Khan IA, Foran CM, Schlenk D (2003) Determination of beta-adrenergic receptor blocking pharmaceuticals in United States wastewater effluent. Environmental Pollution. 121 (2): 199-205.

Isobe T, Shiraishi H, Yasuda M, Shinoda A, Suzuki H, Morita M (2003) Determination of estrogens and their conjugates in water using solid-phase extraction followed by liquid chromatography-tandem mass spectrometry. J Chromatogr A. 984 (2): 195-202.

Jobling S, Casey D, Rodgers-Gray T, Oehlmann J, Schulte-Oehlmann U, Pawlowski S, Baunbeck T, Turner AP, Tyler CR (2003 ) Comparative responses of molluscs and fish to environmental estrogens and an estrogenic effluent. Aquatic Toxicology. 65 (2): 205-220.

Kasprzyk-Hordem B, Dinsdale RM, Guwy AJ (2007) Multi-residue method for the determination of basic/neutral pharmaceuticals and illicit drugs in surface water by solid-phase extraction and ultra performance liquid chromatography-positive electrospray ionisation tandem mass spectrometry. J Chromatogr A. 1161 (1-2): 132-145.

Kasprzyk-Hordern B, Dinsdale RM, Guwy AJ (2009) The removal of pharmaceuticals, personal care products, endocrine disruptors and illicit drugs during wastewater treatment and its impact on the quality of receiving waters. Water Research. 43 (2): 363-380.

Kuch HM, Ballschmiter K (2001) Determination of endocrine-disrupting phenolic compounds and estrogens in surface and drinking water by HRGC-(NCI)-MS in the picogram per liter range. Environ Sci Technol. 35 (15): 3201-3206.

Kummerer K (2009) The presence of pharmaceuticals in the environment due to human use - present knowledge and future challenges. Journal of Environmental Management. 90 (8): 2354-2366.

Kuster M, de Alda MJ, Hernando MD, Petrovic M, Martin-Alonso J, Barcelo D (2008) Analysis and occurrence of pharmaceuticals, estrogens, progestogens and polar pesticides in sewage treatment plant effluents, river water and drinking water in the Llobregat river basin (Barcelona, Spain). Journal of Hydrology. 358 (1-2): 112-123.

Labadie P, Budzinski H (2005) Development of an analytical procedure for determination of selected estrogens and progestagens in water samples. Anal Bioanal Chem. 381 (6): 1199-1205.

Lagana A, Bacaloni A, De Leva I, Faberi A, Fago G, Marino A (2004) Analytical methodologies for determining the occurrence of endocrine disrupting chemicals in sewage treatment plants and natural waters. Analytica Chimica Acta. 501 (1): 79-88.

Larsson DGJ, Adolfsson-Erici M, Parkkonen J, Pettersson M, Berg AH, Olsson PE, Forlin L (1999) Ethinyloestradiol - an undesired fish contraceptive? Aquatic Toxicology. 45 (2-3): 91-97.

Loos R, Gawlik BM, Locoro G, Rimaviciute E, Contini S, Bidoglio G (2009) EU-wide survey of polar organic persistent pollutants in European river waters. Environmental Pollution. 157 (2): 561-568.

Loos R, Wollgast J, Huber T, Hanke G (2007) Polar herbicides, pharmaceutical products, perfluorooctanesulfonate (PFOS), perfluorooctanoate (PFOA), and nonylphenol and its carboxylates and ethoxylates in surface and tap waters around Lake Maggiore in Northern Italy. Anal Bioanal Chem. 387 (4): 1469-1478.

Maurer M, Escher BI, Richle P, Schaffner C, Alder AC (2007) Elimination of beta-blockers in sewage treatment plants. Water Research. 41 (7): 1614-1622.

Miege C, Bados P, Brosse C, Coquery M (2009a) Method validation for the analysis of estrogens (including conjugated compounds) in aqueous matrices. Trends Analyt Chem. 28 (2): 237-244. 
Miege C, Choubert JM, Ribeiro L, Eusebe M, Coquery M (2009b) Fate of pharmaceuticals and personal care products in wastewater treatment plants - Conception of a database and first results. Environmental Pollution. 157 (5): 1721-1726.

Miege C, Karolak S, Gabet V, Jugan ML, Oziol L, Chevreuil M, Levi Y, Coquery M (2009c) Evaluation of estrogenic disrupting potency in aquatic environments and urban wastewaters by combining chemical and biological analysis. Trends Analyt Chem. 28 (2): 186-195.

Miege C, Favier M, Brosse C, Canler JP, Coquery M (2006) Occurrence of betablockers in effluents of wastewater treatment plants from the Lyon area (France) and risk assessment for the downstream rivers. Talanta. 70 (4): 739-744.

Morteani G, Moller P, Fuganti A, Paces T (2006) Input and fate of anthropogenic estrogens and gadolinium in surface water and sewage plants in the hydrological basin of Prague (Czech Republic). Environmental Geochemistry and Health. 28 (3): 257-264.

Nakada N, Tanishima T, Shinohara H, Kiri K, Takada H (2006) Pharmaceutical chemicals and endocrine disrupters in municipal wastewater in Tokyo and their removal during activated sludge treatment. Water Research. 40 (17): 3297-3303.

Paffoni C, Welte B, Gousailles M, Montiel A (2006) New molecules involved by the european directives: from wastewater to drinking water treatment plants. European Journal of Water Quality. 37 (1): 21-38.

Peng XZ, Yu YJ, Tang CM, Tan JH, Huang QX, Wang ZD (2008) Occurrence of steroid estrogens, endocrine-disrupting phenols, and acid pharmaceutical residues in urban riverine water of the Pearl River Delta, South China. Science of the Total Environment. 397 (1-3): 158-166.

Ren HY, Ji SL, Ahmad NUD, Dao W, Cui CW (2007) Degradation characteristics and metabolic pathway of 17 alpha-ethynylestradiol by Sphingobacterium sp JCR5. Chemosphere. 66 (2): 340-346.

Rodriguez-Mozaz S, de Alda MJL, Barcelo D (2004) Monitoring of estrogens, pesticides and bisphenol A in natural waters and drinking water treatment plants by solid-phase extraction-liquid chromatography-mass spectrometry. J Chromatogr A. 1045 (1-2): 85-92.

Stuer-Lauridsen F, Birkved M, Hansen LP, Lutzhoft HCH, Halling-Sorensen B (2000) Environmental risk assessment of human pharmaceuticals in Denmark after normal therapeutic use. Chemosphere. 40 (7): 783 793.

Ternes TA (1998) Occurrence of drugs in German sewage treatment plants and rivers. Water Research. 32 (11): 3245-3260.

Ternes TA, Kreckel P, Mueller J (1999a) Behaviour and occurrence of estrogens in municipal sewage treatment plants - II. Aerobic batch experiments with activated sludge. Science of the Total Environment. 225 (1-2): 91-99.

Ternes TA, Stumpf M, Mueller J, Haberer K, Wilken RD, Servos M (1999b) Behavior and occurrence of estrogens in municipal sewage treatment plants - I. Investigations in Germany, Canada and Brazil. Science of the Total Environment. 225 (1-2): 81-90.

Ternes, T. A. and Joss, A. (2006) Human Pharmaceuticals, Hormones and Fragrances: The challenge of micropollutants in urban water management. IWA Publishing.

Vethaak AD, Lahr J, Schrap SM, Belfroid AC, Rijs GBJ, Gerritsen A, de Boer J, Bulder AS, Grinwis GCM, Kuiper RV, Legler J, Murk TAJ, Peijnenburg W, Verhaar HJM, de Voogt P (2005) An integrated assessment of estrogenic contamination and biological effects in the aquatic environment of The Netherlands. Chemosphere. 59 (4): 511-524.

Vieno NM, Tuhkanen T, Kronberg L (2006) Analysis of neutral and basic pharmaceuticals in sewage treatment plants and in recipient rivers using solid phase extraction and liquid chromatography-tandem mass spectrometry detection. J Chromatogr A. 1134 (1-2): 101-111.

Vigano L, Mandich A, Benfenati E, Bertolotti R, Bottero S, Porazzi E, Agradi E (2006) Investigating the estrogenic risk along the River Po and its intermediate section. Archives of Environmental Contamination and Toxicology. 51 (4): 641-651.

Vulliet E, Wiest L, Baudot R, Grenier-Loustalot MF (2008) Multi-residue analysis of steroids at sub-ng/L levels in surface and ground-waters using liquid chromatography coupled to tandem mass spectrometry. $\mathbf{J}$ Chromatogr A. 1210 (1): 84-91.

Zhou JL, Zhang ZL, Banks E, Grover D, Jiang JQ (2009) Pharmaceutical residues in wastewater treatment works effluents and their impact on receiving river water. Journal of Hazardous Materials. 166 (2-3): 655661. 


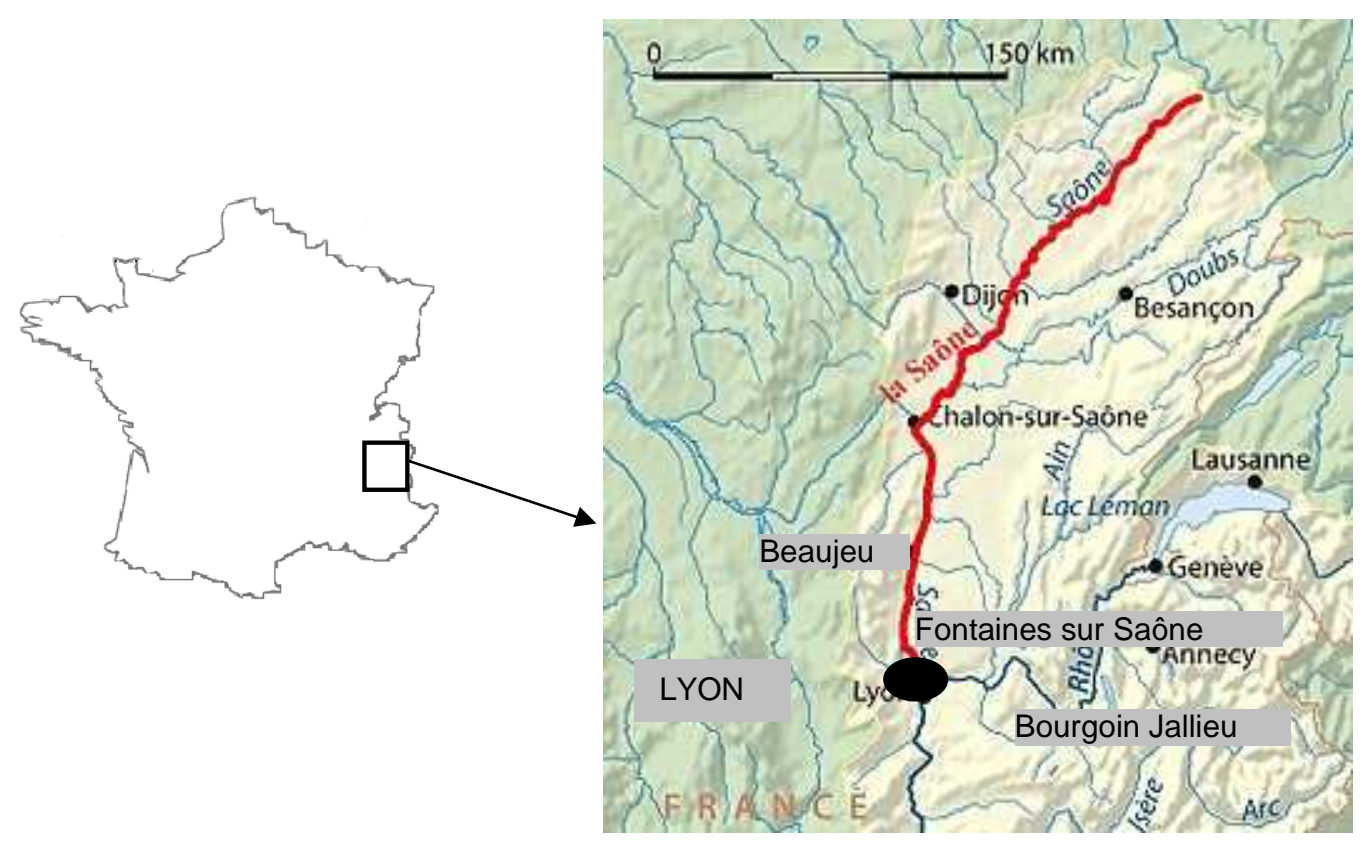

Figure 1. Location of the three sampling sites near Lyon, France

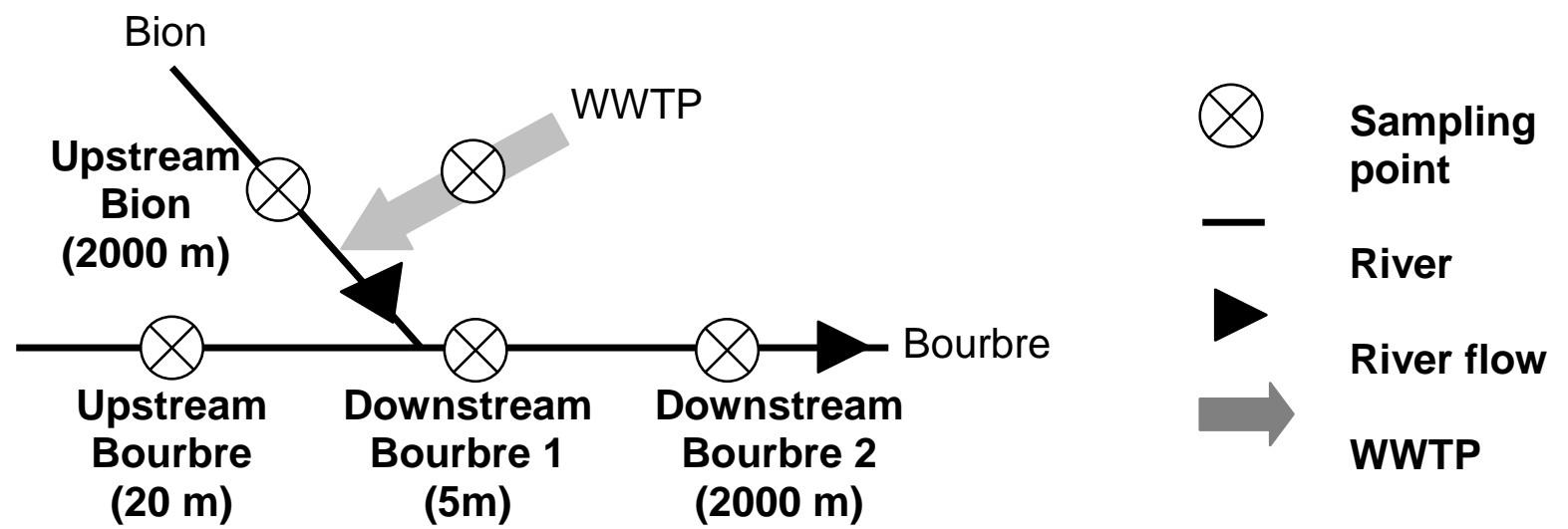

Figure 2. Configuration of the sampling points on the Bourgoin-Jallieu site 

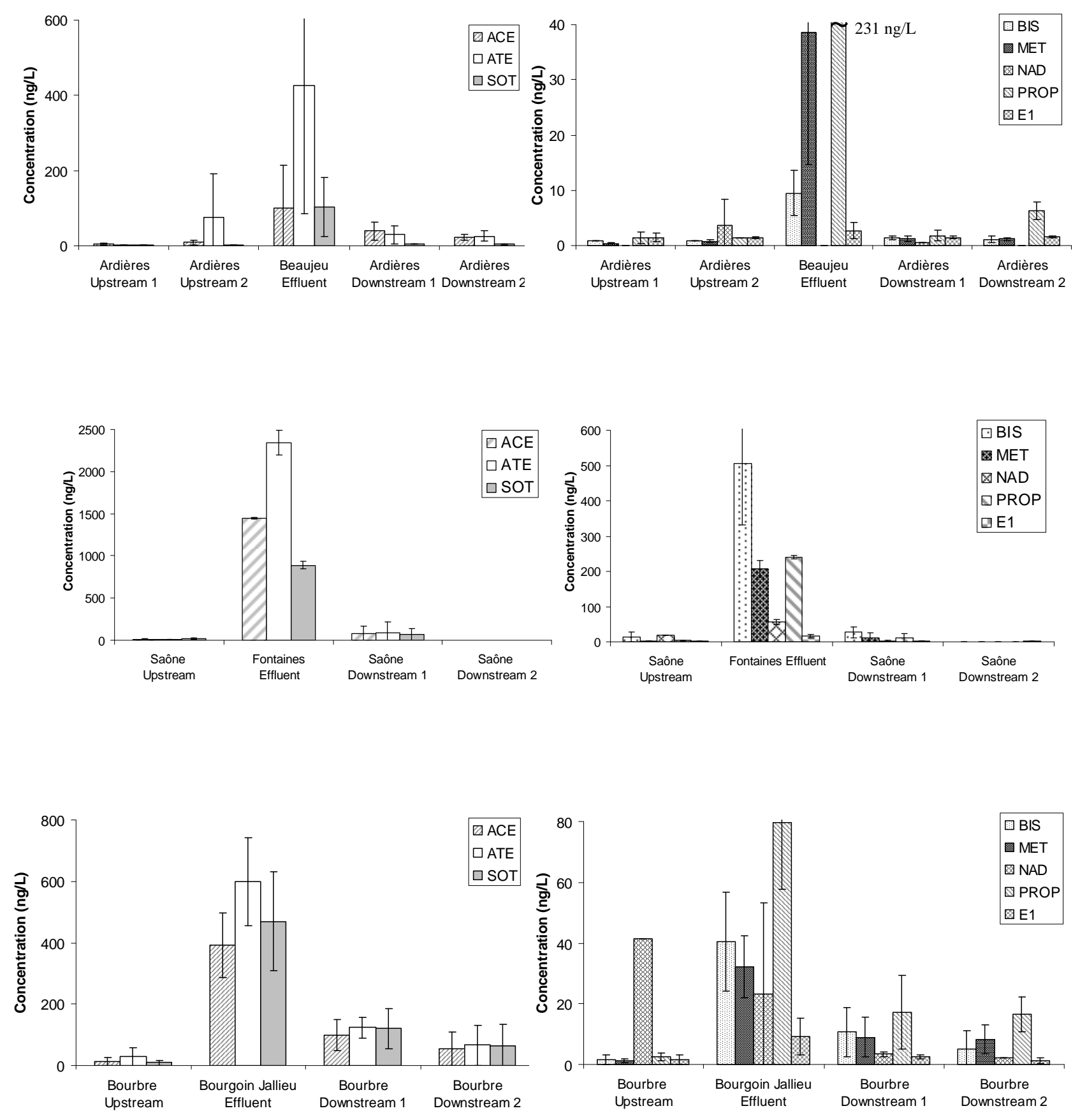

Figure 3. Mean concentrations $( \pm \mathrm{sd}$ ) of estrogens and betablockers at the different sampling stations of the three sites studied (a, Ardières; b, Bourbre; c, Fontaines-sur-Saône)

Some data not shown (cf. Table 2): $\alpha \mathrm{E} 2, \beta \mathrm{E} 2$ and EE2 were never quantified; E3 only quantified in Fontaines-sur-Saône (in all effluents and in one surface water sample); BET and OXP only quantified in the samples from Fontaines-sur-Saône (mean concentrations below $2 \mathrm{ng} / \mathrm{L}$ for surface water and of 18 and 30 $\mathrm{ng} / \mathrm{L}$ in effluents for BET and OXP, respectively); TIM only quantified at low levels (mean concentrations below $3 \mathrm{ng} / \mathrm{L}$ in surface water and between 2.9 and $8.7 \mathrm{ng} / \mathrm{L}$ in effluent samples) 


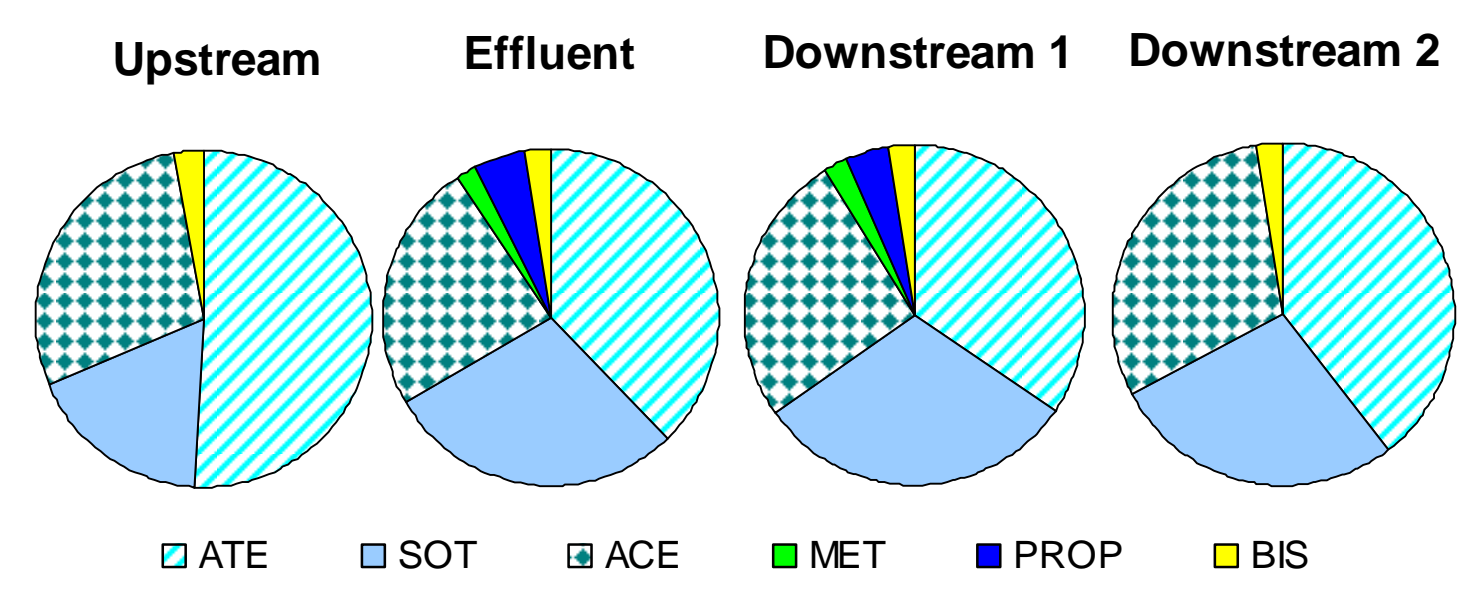

Figure 4. Relative abundance (\%) of quantified betablockers for each sampling station in the River Bourbre and in the effluent from the Bourgoin-Jallieu WWTP 
Table 1. Information on WWTP and sampling campaigns

\begin{tabular}{|c|c|c|c|c|c|}
\hline \multirow[b]{2}{*}{$\begin{array}{l}\text { Treatment } \\
\text { process }\end{array}$} & \multicolumn{2}{|l|}{ WWTP } & \multirow[b]{2}{*}{$\begin{array}{l}\text { Receiving } \\
\text { River }\end{array}$} & \multirow[t]{2}{*}{ Sampling points } & \multirow[t]{2}{*}{ Sampling period } \\
\hline & $\begin{array}{l}\text { Population } \\
\text { equivalent } \\
\text { (PE) }\end{array}$ & $\begin{array}{l}\text { Flow } \\
(\mathrm{m} 3 / \mathrm{d})\end{array}$ & & & \\
\hline $\begin{array}{l}\text { Low loaded } \\
\text { activated sludge } \\
(\mathrm{C}+\mathrm{N})^{*}\end{array}$ & 2900 & 750 & Ardières & $\begin{array}{l}\text { Upstream } 1(4000 \mathrm{~m}) \\
\text { Upstream } 2(20 \mathrm{~m}) \\
\text { Effluent } \\
\text { Downstream } 1(5 \mathrm{~m}) \\
\text { Downstream } 2(20 \mathrm{~m})\end{array}$ & June 2008 \\
\hline $\begin{array}{l}\text { Primary settling } \\
+ \text { medium-rate } \\
\text { activated sludge }\end{array}$ & 78000 & 17500 & Bourbre & Cf Figure 2. & Sept. 2008 \\
\hline $\begin{array}{l}\text { Primary settling } \\
+ \text { Biological filter } \\
(\mathrm{C}+\mathrm{N})\end{array}$ & 30000 & 6500 & Saône & $\begin{array}{l}\text { Upstream }(200 \mathrm{~m}) \\
\text { Effluent } \\
\text { Downstream 1 }(50 \mathrm{~m}) \\
\text { Downstream 2 }(200 \mathrm{~m})\end{array}$ & $\begin{array}{l}\text { Nov. } 2007 \\
\text { and June } 2008\end{array}$ \\
\hline
\end{tabular}

* conventional activated sludge

Table 2. Concentrations of estrogens and betablockers measured in effluent and surface water samples of three sites in France (Rivers Ardières, Bourbre and Saône and WWTPs) from November 2007 to September 2008

\begin{tabular}{lcccccccccc}
\hline & $\begin{array}{c}\text { Quantification } \\
\text { frequency } \\
(\%)\end{array}$ & \multicolumn{2}{c}{$\begin{array}{c}\text { Mean } \\
\text { (ng/L) }\end{array}$} & \multicolumn{2}{c}{$\begin{array}{c}\text { Median } \\
(\mathbf{n g} / \mathbf{L})\end{array}$} & \multicolumn{2}{c}{$\begin{array}{c}\text { Min } \\
(\mathbf{n g} / \mathbf{L})\end{array}$} & \multicolumn{2}{c}{$\begin{array}{c}\text { Max } \\
(\mathbf{n g} / \mathbf{L})\end{array}$} \\
& Eff. & SW & Eff. & SW & Eff. & SW & Eff. & SW & Eff. & SW \\
\hline E1 & 100 & 98 & 9.3 & 1.6 & 8.7 & 1.5 & 1.7 & 0.3 & 20 & 3.9 \\
E3 & 25 & 2 & 210 & 26 & 210 & 26 & 202 & 26 & 218 & 26 \\
\hline ACE & 100 & 100 & 595 & 35 & 381 & 14 & 68 & 3.0 & 1455 & 183 \\
ATE & 100 & 97 & 1043 & 50 & 705 & 17 & 388 & 0.4 & 2450 & 240 \\
BET & 25 & 15 & 18 & 0.6 & 18 & 0.4 & 17 & 0.2 & 19 & 1.7 \\
BIS & 100 & 82 & 149 & 7.3 & 37 & 1.7 & 6.6 & 0.3 & 630 & 38 \\
MET & 100 & 71 & 77 & 4.4 & 38 & 1.8 & 22 & 0.4 & 223 & 29 \\
NAD & 50 & 32 & 40 & 9.2 & 48 & 4.0 & 2.1 & 0.4 & 61 & 42 \\
OXP & 38 & 9 & 20 & 1.3 & 27 & 0.3 & 0.8 & 0.1 & 32 & 3.4 \\
PROP & 100 & 65 & 158 & 8.1 & 138 & 4.6 & 62 & 0.7 & 294 & 35 \\
SOT & 100 & 91 & 495 & 34 & 435 & 5.5 & 97 & 1.6 & 918 & 213 \\
TIM & 88 & 44 & 4.6 & 1.5 & 3.6 & 1.6 & 1.5 & 0.8 & 9.5 & 2.0 \\
\hline
\end{tabular}

Eff.: effluent ( $n=8$ for estrogens and betablockers)

SW: surface water ( $n=42$ for estrogens and 34 for betablockers)

$(\alpha \mathrm{E} 2, \beta \mathrm{E} 2, \mathrm{EE} 2$ never detected $)$ 
Table 3. Increase ratio for betablocker concentrations in river samples from upstream to downstream of the WWTP outfall and attenuation (\%) measured between the two sampling stations downstream of the WWTP outfall

\begin{tabular}{|c|c|c|c|c|c|c|c|c|c|c|c|}
\hline & WWTP & River & $\begin{array}{l}\text { Dilution factor of } \\
\text { effluent in river }\end{array}$ & ACE & ATE & BIS & MET & NAD & PROP & SOT & TIM \\
\hline \multirow{4}{*}{$\begin{array}{l}\text { Increase } \\
\text { ratio }\end{array}$} & Bourgoin & Bourbre & 14 & & & & & & & & \\
\hline & Jallieu & & & 6 & 3 & 6 & 6 & -1 & 6 & 13 & 1 \\
\hline & Beaujeu & Ardières & 70 & 3 & $12 *$ & 0 & 1 & -1 & 0 & 1 & 0 \\
\hline & Fontaines & Saône & 7000 & 4 & 8 & 1 & 5 & -1 & 2 & 2 & 1 \\
\hline \multirow[t]{3}{*}{$\begin{array}{l}\text { Attenuation } \\
(\%)\end{array}$} & $\begin{array}{l}\text { Bourgoin } \\
\text { Jallieu }\end{array}$ & $\begin{array}{l}\text { Bourbre } \\
(2 \mathrm{~km})\end{array}$ & 14 & 53 & 61 & 61 & 9 & $\mathrm{nc}$ & 5 & 51 & $\mathrm{nc}$ \\
\hline & Beaujeu & Ardières & 70 & & & & & & & & \\
\hline & & $(20 \mathrm{~m})$ & & 54 & 11 & $\mathrm{nc}$ & $\mathrm{nc}$ & $\mathrm{nc}$ & $\mathrm{nc}$ & 47 & nc \\
\hline
\end{tabular}

*calculated with upstream $4000 \mathrm{~m}$ before WWTP outfall, because of one suspicious concentration for upstream $20 \mathrm{~m}$ before WWTP outfall nc: attenuation not calculated because measurements were too close to limits of quantification. 
1 Table 4. Predicted environmental concentrations (PEC) and measured concentrations (MEC, min-max) at the different sampling stations of the three rivers studied 2 downstream of the WWTP outfall

\begin{tabular}{|c|c|c|c|c|c|c|c|c|c|c|c|c|c|c|c|c|}
\hline \multirow{2}{*}{$\begin{array}{l}\text { WWTP and } \\
\text { River }\end{array}$} & \multirow{2}{*}{$\begin{array}{l}\text { Sampling } \\
\text { day }\end{array}$} & \multirow{2}{*}{$\begin{array}{l}\text { WWT } \\
\text { P flow } \\
\left(\mathbf{m}^{3} / \mathbf{s}\right)\end{array}$} & \multirow{2}{*}{$\begin{array}{c}\text { QMNA5 } \\
\left(\mathbf{m}^{3} / \mathbf{s}\right)\end{array}$} & & \multicolumn{12}{|c|}{ Concentration (ng/L) } \\
\hline & & & & & E1 tot & E3 tot & ATE & SOT & NAD & TIM & ACE & MET & OXP & PROP & BET & BIS \\
\hline Fontaines - & $13 / 11 / 07$ & 124 & 40 & PEC & 0.03 & 0.3 & 3,4 & 1,3 & 0,1 & 0,01 & 2,2 & 0,3 & 0,05 & 0,4 & 0,03 & 1,0 \\
\hline Saône River & $16 / 11 / 07$ & 267 & 40 & $\begin{array}{c}\text { MEC } \\
\text { PEC } \\
\text { MEC }^{\mathrm{b}}\end{array}$ & $\begin{array}{c}0.8-3.8 \\
0.02^{\mathrm{a}} \\
0.7-0.8\end{array}$ & $\begin{array}{l}<0.2 \\
0.3^{\mathrm{a}} \\
<2.6 \\
\end{array}$ & $\begin{array}{c}9.8-26.5 \\
3,5 \\
10.1-13.8 \\
\end{array}$ & $\begin{array}{c}<8.9-153 \\
1,3 \\
24.5-28.0\end{array}$ & $\begin{array}{c}<1.0-1.0 \\
0,1 \\
<1.1\end{array}$ & $\begin{array}{l}<1.3 \\
0,01 \\
<1.0\end{array}$ & $\begin{array}{c}11.7-23.2 \\
2,1 \\
17.9-21.0\end{array}$ & $\begin{array}{c}1.8-4.4 \\
0,3 \\
1.7-2.1 \\
\end{array}$ & $\begin{array}{c}0.1-0.3 \\
0,04 \\
<0.9 \\
\end{array}$ & $\begin{array}{c}<0.8-4.1 \\
0,3 \\
4.8-5.7\end{array}$ & $\begin{array}{c}0.2-0.4 \\
0,02 \\
<0.9 \\
\end{array}$ & $\begin{array}{c}29.6-34.7 \\
0,5 \\
9.0-11.2\end{array}$ \\
\hline $\begin{array}{l}\text { Beaujeu - } \\
\text { Ardières }\end{array}$ & $10 / 06 / 08$ & 0.827 & 0.444 & $\begin{array}{l}\text { PEC } \\
\text { MEC }\end{array}$ & $\begin{array}{c}0.1 \\
1.2-1.6\end{array}$ & I & $\begin{array}{c}32.1 \\
0.4-19.6\end{array}$ & $\begin{array}{c}8.0 \\
<0.4-5.8\end{array}$ & $\begin{array}{c}\prime \\
<0.2-0.6\end{array}$ & $\begin{array}{c}0.23 \\
1.7-2.0\end{array}$ & $\begin{array}{c}5.6 \\
3.0-13.2\end{array}$ & $\begin{array}{c}1.8 \\
<0.3-1.8\end{array}$ & $\begin{array}{c}0.1 \\
<0.3\end{array}$ & $\begin{array}{c}13.8 \\
<0.4-6.9\end{array}$ & $\begin{array}{c}\prime \\
<0.3-0.5\end{array}$ & $\begin{array}{c}0.5 \\
<0.2-1.6\end{array}$ \\
\hline River & $24 / 06 / 08$ & 0.345 & 0.444 & $\begin{array}{l}\text { PEC } \\
\text { MEC }\end{array}$ & $\begin{array}{c}0.3 \\
0.8-1.8\end{array}$ & i & $\begin{array}{c}65.1 \\
<0.8-209\end{array}$ & $\begin{array}{c}15.6 \\
<0.1-5.0\end{array}$ & $\begin{array}{c}/ \\
<0.2-7.1\end{array}$ & $\begin{array}{c}0.3 \\
1.6-1.8\end{array}$ & $\begin{array}{c}16.9 \\
3.1-43.5\end{array}$ & $\begin{array}{c}4.2 \\
0.4-1.0\end{array}$ & $\begin{array}{l}0.5 \\
1\end{array}$ & $\begin{array}{c}22.1 \\
<0.5-7.4\end{array}$ & $\begin{array}{c}1 \\
1 \\
1\end{array}$ & $\begin{array}{c}0.9 \\
<0.3-0.4\end{array}$ \\
\hline Bourgoin & $02 / 09 / 08$ & $2.07^{\mathrm{b}}$ & 0.105 & $\begin{array}{l}\mathrm{PEC} \\
\mathrm{MFC}\end{array}$ & $\begin{array}{c}1.8 \\
15-19\end{array}$ & 1 & $\begin{array}{c}165 \\
735-165\end{array}$ & $\begin{array}{c}243 \\
192-213\end{array}$ & $\begin{array}{c}15.6 \\
23-415\end{array}$ & $\begin{array}{c}1.4 \\
<01-10\end{array}$ & $\begin{array}{c}151 \\
333-168\end{array}$ & $\begin{array}{c}16.5 \\
18-185\end{array}$ & 1 & $\begin{array}{c}38.4 \\
34-345\end{array}$ & I & $\begin{array}{c}22.1 \\
37-209\end{array}$ \\
\hline $\begin{array}{l}\text { Bourbre } \\
\text { River }\end{array}$ & 09/09/08 & 2.41 & 0.105 & PEC & 1.4 & 1 & $\begin{array}{l}202 \\
117-125\end{array}$ & $\begin{array}{c}179 \\
34-113\end{array}$ & $\begin{array}{c}1 \\
<03-28\end{array}$ & 1 & $\begin{array}{l}129 \\
76-110\end{array}$ & $\begin{array}{c}10.6 \\
<02-83\end{array}$ & i & $\begin{array}{c}24.3 \\
<03-161\end{array}$ & i & $\begin{array}{c}16.2 \\
0 .-137\end{array}$ \\
\hline River & 16/09/08 & 4.70 & 0.105 & $\begin{array}{l}\text { MEC } \\
\text { PEC }\end{array}$ & $\begin{array}{c}0.3-2.3 \\
5.0\end{array}$ & I & 251 & $\begin{array}{c}3.4-113 \\
128\end{array}$ & $\begin{array}{c}0.3-2.8 \\
1\end{array}$ & 0.6 & 118 & $\begin{array}{c}0.2-8.3 \\
10.2\end{array}$ & I & $\begin{array}{c}<0.3-16.1 \\
25.9\end{array}$ & I & $\begin{array}{c}0.5-13.7 \\
10.4\end{array}$ \\
\hline & 23/09/08 & 2.27 & 0.105 & $\begin{array}{l}\text { MEC } \\
\text { PEC } \\
\text { MEC }\end{array}$ & $\begin{array}{c}0.4-3.3 \\
5.9 \\
2.1-3.9\end{array}$ & $\begin{array}{l}1 \\
1 \\
1\end{array}$ & $\begin{array}{c}10.9-118 \\
292 \\
16.3-103\end{array}$ & $\begin{array}{c}4.5-94.3 \\
151 \\
5.5-80.4\end{array}$ & $\begin{array}{c}\prime \\
0.8 \\
<0.5\end{array}$ & $\begin{array}{l}<0.5 \\
1.2 \\
<0.6\end{array}$ & $\begin{array}{c}5.8-59.5 \\
191 \\
9.5-111\end{array}$ & $\begin{array}{c}<0.3-5.0 \\
10.9 \\
0.8-4.9\end{array}$ & $\begin{array}{l}1 \\
1 \\
1\end{array}$ & $\begin{array}{c}<0.4-10.7 \\
30.8 \\
1.5-12.5\end{array}$ & $\begin{array}{c}\text { I } \\
\text { / } \\
<0.2-0.4\end{array}$ & $\begin{array}{c}0.3-3.5 \\
11.8 \\
1.9-6.4\end{array}$ \\
\hline
\end{tabular}

3

QMNA5: 5-year lowest water flow discharges

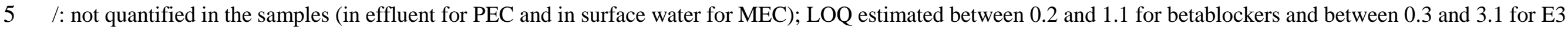

6 a free concentration

$7{ }^{\mathrm{b}}$ MEC of the $20 / 11 / 07$ 
9 Table 5. Risk assessment for estrogens (total risk) and four betablockers (ACE, ATE, MET and PROP) in rivers downstream of WWTP outfall et 15 sites in

10 France

\begin{tabular}{|c|c|c|c|c|c|c|c|c|c|c|c|c|c|c|c|c|c|c|c|}
\hline \multirow[t]{2}{*}{ WWTP } & \multirow[t]{2}{*}{ River } & \multirow{2}{*}{$\begin{array}{c}\text { Population } \\
\text { equivalent } \\
\text { (PE) }\end{array}$} & \multirow{2}{*}{$\begin{array}{c}\text { WWTP } \\
\text { outflow } \\
\left(\mathbf{m}^{3} / \mathbf{d}\right)\end{array}$} & \multirow[b]{2}{*}{$\begin{array}{c}5 \text { years } \\
\text { lowest water } \\
\text { flow } \\
\text { discharges } \\
\left(\mathrm{m}^{3} / \mathbf{s}\right)\end{array}$} & \multirow{2}{*}{$\begin{array}{l}\text { Calculated } \\
\text { dilution } \\
\text { factor }\end{array}$} & \multicolumn{9}{|c|}{ MEC (mean value) or PEC (ng/L) } & \multicolumn{5}{|c|}{ PEC/PNEC ratio } \\
\hline & & & & & & E1 & $\alpha \mathbf{E} 2$ & $\beta E 2$ & E3 & EE2 & ACE & ATE & MET & PROP & $\begin{array}{c}\text { Sum of } \\
\text { estrogens }\end{array}$ & ACE & ATE & MET & PROP \\
\hline Beaujeu & Ardières & 2900 & 750 & 0.11 & 13 & 1.5 & 1 & 1 & I & I & 19.0 & 36.2 & 0.9 & 3.2 & 0.3 & $<0.1$ & $<0.1$ & $<0.1$ & 0.3 \\
\hline $\begin{array}{c}\text { Bourgoin } \\
\text { Jallieu }\end{array}$ & Bourbre & 78000 & 17500 & 0.44 & 2 & 1.8 & I & I & 1 & 1 & 76.3 & 94.4 & 8.8 & 17.0 & 0.4 & $<0.1$ & $<0.1$ & $<0.1$ & 1.7 \\
\hline $\begin{array}{l}\text { Fontaines } \\
\text { sur Saône }\end{array}$ & Saône & 30000 & 6500 & 40 & 532 & 1.6 & I & I & 25.9 & I & 44.7 & 51.7 & 6.9 & 8.4 & 5.5 & $<0.1$ & $<0.1$ & $<0.1$ & 0.8 \\
\hline 1 & Maurepas & 36000 & 4430 & 0.11 & 2 & 3.1 & I & I & I & I & 18.1 & 400 & 28.9 & 179 & 0.6 & $<0.1$ & 0.1 & $<0.1$ & 17.8 \\
\hline 2 & Seine & 250000 & 26737 & 63.0 & 204 & $0.3 * 10^{-2}$ & I & I & I & I & 0.2 & 2.0 & 1.2 & 1.2 & 0.0 & $<0.1$ & $<0.1$ & $<0.1$ & \\
\hline 3 & Maldroit & 50000 & 6486 & 0.09 & 1 & 3.9 & l & I & I & I & 155 & 277 & 34.9 & 217 & 0.8 & $<0.1$ & $<0.1$ & $<0.1$ & $\begin{array}{c}0.1 \\
21.7\end{array}$ \\
\hline 4 & $\begin{array}{c}\text { Gave of } \\
\text { Pau }\end{array}$ & 110000 & 14513 & 14.0 & 83 & $0.9^{*} 10^{-2}$ & I & I & I & I & 1.2 & 7.3 & 1.6 & 1.9 & $<0.1$ & $<0.1$ & $<0.1$ & $<0.1$ & 0.2 \\
\hline 5 & $\begin{array}{l}\text { Vallon St } \\
\text { Antoine }\end{array}$ & 24000 & 1459 & 0.78 & 46 & $0.4^{*} * 10^{-2}$ & I & I & I & I & 3.6 & 9.7 & 0.5 & 2.6 & $<0.1$ & $<0.1$ & $<0.1$ & $<0.1$ & 0.3 \\
\hline 6 & Bouillide & 26000 & 3750 & 0.02 & 1 & 0.8 & I & I & I & I & 518 & 1378 & 165 & 342 & 0.2 & $<0.1$ & 0.2 & $<0.1$ & 34.2 \\
\hline 7 & $\begin{array}{c}\text { CanteRan } \\
\mathrm{e}\end{array}$ & 1000 & 81 & 0.03 & 34 & 1.5 & 0.2 & 0.3 & 0.7 & 1 & 1 & 1 & 1 & 2.2 & 0.5 & $<0.1$ & $<0.1$ & $<0.1$ & 0.2 \\
\hline 8 & Ardières & 2900 & 674 & 0.10 & 13 & 0.6 & I & 1 & I & I & 15.6 & 55.7 & 2.3 & 26.3 & 0.1 & $<0.1$ & $<0.1$ & $<0.1$ & 2.6 \\
\hline 9 & Rhône & 13000 & 1061 & 600 & 48860 & $0.3 * 10^{-3}$ & I & $0.5^{*} 10^{-4}$ & I & I & $0.4 * 10^{-2}$ & $0.2 * 10^{-1}$ & $0.1 * 10^{-1}$ & $0.3 * 10^{-2}$ & $<0.1$ & $<0.1$ & $<0.1$ & $<0.1$ & $<0.1$ \\
\hline 10 & Rhône & 700000 & 312767 & 600 & 166 & $0.4 * 10^{-1}$ & 1 & 1 & 1 & 1 & 1 & 8.2 & 1.2 & 1.2 & $<0.1$ & $<0.1$ & $<0.1$ & $<0.1$ & 0.1 \\
\hline 11 & Rhône & 88000 & 7150 & 600 & 7250 & $0.1 * 10^{-2}$ & $0.3 * 10^{-3}$ & $0.4 * 10^{-3}$ & $0.7 * 10^{-2}$ & $\frac{0.3 * 10^{-}}{3}$ & 0.4 & 0.3 & 0.1 & 0.1 & 0.0 & $<0.1$ & 0.0 & 0.0 & 0.0 \\
\hline 12 & Arvan & 17000 & 1198 & 0.74 & 54 & 0.1 & 1 & 0.3 & 0.6 & 1 & 15.8 & 8.9 & 5.0 & 3.6 & 0.2 & $<0.1$ & 0.0 & 0.0 & 0.4 \\
\hline
\end{tabular}

/: not quantified

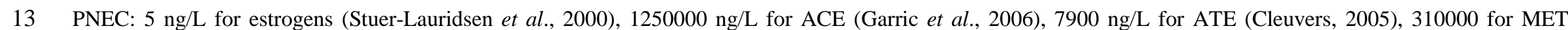

14 (Cleuvers, 2005) and $10 \mathrm{ng} / \mathrm{L}$ for PROP (Ferrari et al., 2004). 
17 Supplementary material. Mean concentrations (min-max, in ng/L) of estrogens and betablockers measured in the different sampling points of the three sites studied

\begin{tabular}{|c|c|c|c|c|c|c|c|c|c|c|c|c|}
\hline & & ACE & ATE & BIS & BET & MET & NAD & OXP & PROP & SOT & TIM & E1 \\
\hline Bourbre & $\begin{array}{l}\text { Upstream } \\
(20 \mathrm{~m})\end{array}$ & $\begin{array}{c}14 \\
(6.0-33)\end{array}$ & $\begin{array}{c}28 \\
(11-74)\end{array}$ & $\begin{array}{c}1.6 \\
(0.3-3.7)\end{array}$ & 1 & $\begin{array}{c}1.3^{\mathrm{c}} \\
(0.8-1.8)\end{array}$ & $\begin{array}{c}42^{\mathrm{a}} \\
(42-42)\end{array}$ & 1 & $\begin{array}{c}2.5^{\mathrm{c}} \\
(1.5-3.4)\end{array}$ & $\begin{array}{c}8.4 \\
(3.4-19)\end{array}$ & I & $\begin{array}{c}1.6 \\
(0.5-3.9)\end{array}$ \\
\hline $\begin{array}{c}\text { Bourgoin } \\
\text { Jallieu } \\
\text { WWTP }\end{array}$ & Effluent & $\begin{array}{c}393 \\
(289-521)\end{array}$ & $\begin{array}{c}599 \\
(470-796)\end{array}$ & $\begin{array}{c}41 \\
(26-63)\end{array}$ & I & $\begin{array}{c}32 \\
(25-47)\end{array}$ & $\begin{array}{c}23 \\
(2.1-45)\end{array}$ & I & $\begin{array}{c}80 \\
(62-110)\end{array}$ & $\begin{array}{c}470 \\
(315-695)\end{array}$ & $\begin{array}{c}2.9 \\
(1.5-3.9)\end{array}$ & $\begin{array}{c}9.2 \\
(3.5-16.1)\end{array}$ \\
\hline Bourbre & $\begin{array}{c}\text { Downstream } \\
1(5 \mathrm{~m})\end{array}$ & $\begin{array}{c}99 \\
(58-168)\end{array}$ & $\begin{array}{c}123 \\
(85-165)\end{array}$ & $\begin{array}{c}11 \\
(3.5-21)\end{array}$ & I & $\begin{array}{c}9.0 \\
(4.4-19)\end{array}$ & $\begin{array}{c}3.4^{\mathrm{c}} \\
(2.8-4.0)\end{array}$ & I & $\begin{array}{c}17 \\
(7.6-35)\end{array}$ & $\begin{array}{c}120 \\
(60-213)\end{array}$ & $\begin{array}{c}1.0^{\mathrm{a}} \\
(1.0-1.0)\end{array}$ & $\begin{array}{c}2.5 \\
(1.9-3.3)\end{array}$ \\
\hline Bourbre & $\begin{array}{c}\text { Downstream } \\
2(2000 \mathrm{~m})\end{array}$ & $\begin{array}{c}54 \\
(5.8-111)\end{array}$ & $\begin{array}{c}65 \\
(10-137)\end{array}$ & $\begin{array}{c}5.2 \\
(0.3-13)\end{array}$ & I & $\begin{array}{c}8.3^{\mathrm{c}} \\
(4.9-12)\end{array}$ & $\begin{array}{c}2.3^{\mathrm{a}} \\
(2.3-2.3)\end{array}$ & I & $\begin{array}{c}16^{\mathrm{c}} \\
(12-21)\end{array}$ & $\begin{array}{c}63 \\
(4.5-158)\end{array}$ & $\begin{array}{c}0.8^{\mathrm{a}} \\
(0.8-0.8)\end{array}$ & $\begin{array}{c}1.2 \\
(0.3-2.1)\end{array}$ \\
\hline Ardières & $\begin{array}{l}\text { Upstream } \\
1(4000 \mathrm{~m})\end{array}$ & $\begin{array}{c}5.0 \\
(3.1-7.3)\end{array}$ & $\begin{array}{c}2.2^{\mathrm{d}} \\
(2.1-2.4)\end{array}$ & $\begin{array}{c}0.9^{\mathrm{d}} \\
(0.9-0.9)\end{array}$ & 1 & $\begin{array}{c}0.4^{\mathrm{d}} \\
(0.4-0.5)\end{array}$ & I & 1 & $\begin{array}{c}1.4^{\mathrm{d}} \\
(0.7-2.1)\end{array}$ & $\begin{array}{c}2.3^{\mathrm{d}} \\
(1.6-3.0)\end{array}$ & $\begin{array}{c}1.8 \\
(1.5-2.0)\end{array}$ & $\begin{array}{c}1.4 \\
(0.8-2.3)\end{array}$ \\
\hline Ardières & $\begin{array}{l}\text { Upstream } \\
2(20 \mathrm{~m})\end{array}$ & $\begin{array}{c}9.1 \\
(3.0-16)\end{array}$ & $\begin{array}{c}76 \\
(0.4-209)\end{array}$ & $\begin{array}{c}1.0^{\mathrm{b}} \\
(1.0-1.0)\end{array}$ & I & $\begin{array}{c}0.7^{\mathrm{d}} \\
(0.5-0.9)\end{array}$ & $\begin{array}{c}3.7^{\mathrm{d}} \\
(0.4-7.1)\end{array}$ & I & $\begin{array}{c}1.4^{\mathrm{b}} \\
(1.4-1.4)\end{array}$ & $\begin{array}{c}3.5^{\mathrm{d}} \\
(3.3-3.6)\end{array}$ & $\begin{array}{c}1.6 \\
(1.4-1.8)\end{array}$ & $\begin{array}{c}1.4 \\
(1.2-1.5)\end{array}$ \\
\hline $\begin{array}{l}\text { Beaujeu } \\
\text { WWTP }\end{array}$ & Effluent & $\begin{array}{c}147 \\
(68-226)\end{array}$ & $\begin{array}{c}628 \\
(388-868)\end{array}$ & $\begin{array}{c}9.5 \\
(6.6-12)\end{array}$ & I & $\begin{array}{c}39 \\
(22-55)\end{array}$ & I & I & $\begin{array}{c}231 \\
(167-294)\end{array}$ & $\begin{array}{c}153 \\
(97-208)\end{array}$ & $\begin{array}{c}3.2 \\
(2.8-3.6)\end{array}$ & $\begin{array}{c}2.7 \\
(1.7-3.7)\end{array}$ \\
\hline Ardières & $\begin{array}{c}\text { Downstream } \\
1(5 \mathrm{~m})\end{array}$ & $\begin{array}{c}39 \\
(12-62)\end{array}$ & $\begin{array}{c}29 \\
(13-56)\end{array}$ & $\begin{array}{c}1.4^{\mathrm{d}} \\
(1.2-1.6)\end{array}$ & I & $\begin{array}{c}1.2 \\
(0.9-1.8)\end{array}$ & $\begin{array}{c}0.6^{\mathrm{b}} \\
(0.6-0.6)\end{array}$ & I & $\begin{array}{c}1.8 \\
(1.1-2.9)\end{array}$ & $\begin{array}{c}5.2 \\
(4.9-5.8)\end{array}$ & $\begin{array}{c}1.6 \\
(1.3-1.8)\end{array}$ & $\begin{array}{c}1.4 \\
(1.1-1.6)\end{array}$ \\
\hline Ardières & $\begin{array}{l}\text { Downstream } \\
2(20 \mathrm{~m})\end{array}$ & $\begin{array}{c}23 \\
(13-30)\end{array}$ & $\begin{array}{c}26 \\
(19-41)\end{array}$ & $\begin{array}{c}1.1 \\
(0.4-1.1)\end{array}$ & I & $\begin{array}{c}1.2 \\
(1.0-1.4)\end{array}$ & l & I & $\begin{array}{c}6.3 \\
(4.5-7.4)\end{array}$ & $\begin{array}{c}4.4 \\
(3.5-5.1)\end{array}$ & $\begin{array}{c}1.6 \\
(1.5-1.7)\end{array}$ & $\begin{array}{c}1.6 \\
(1.5-1.8)\end{array}$ \\
\hline Saône & $\begin{array}{c}\text { Upstream } \\
(200 \mathrm{~m})\end{array}$ & $\begin{array}{c}14 \\
(12-18)\end{array}$ & $\begin{array}{c}10 \\
(9.8-10)\end{array}$ & $\begin{array}{c}14 \\
(1.3-30)\end{array}$ & $\begin{array}{c}0.2^{\mathrm{b}} \\
(0.2-0.2)\end{array}$ & $\begin{array}{c}1.9 \\
(1.7-2.3)\end{array}$ & $\begin{array}{c}18^{\mathrm{b}} \\
(18-18)\end{array}$ & $\begin{array}{c}0.1^{\mathrm{b}} \\
(0.1-0.1)\end{array}$ & $\begin{array}{c}3.8^{\mathrm{d}} \\
(2.8-4.8)\end{array}$ & $\begin{array}{c}22 \\
(16-28)\end{array}$ & I & $\begin{array}{c}1.4 \\
(1.9-0.7)\end{array}$ \\
\hline $\begin{array}{c}\text { Fontaines } \\
\text { sur Saône } \\
\text { WWTP }\end{array}$ & Effluent & $\begin{array}{c}1446 \\
(1436-1455)\end{array}$ & $\begin{array}{c}2345 \\
(2240-2450)\end{array}$ & $\begin{array}{c}507 \\
(383-630)\end{array}$ & $\begin{array}{c}18 \\
(17-19)\end{array}$ & $\begin{array}{c}206 \\
(190-223)\end{array}$ & $\begin{array}{c}56 \\
(52-61)\end{array}$ & $\begin{array}{c}30 \\
(27-32)\end{array}$ & $\begin{array}{c}240 \\
(237-243)\end{array}$ & $\begin{array}{c}886 \\
(855-918)\end{array}$ & $\begin{array}{c}8.7 \\
(8.0-9.5)\end{array}$ & $\begin{array}{c}16.2 \\
(12.4-20)\end{array}$ \\
\hline Saône & $\begin{array}{c}\text { Downstream } \\
1(50 \mathrm{~m})\end{array}$ & $\begin{array}{c}76 \\
(21-183)\end{array}$ & $\begin{array}{c}93 \\
(14-240)\end{array}$ & $\begin{array}{c}27 \\
(9.0-38)\end{array}$ & $\begin{array}{c}1.1^{\mathrm{d}} \\
(0.4-1.7)\end{array}$ & $\begin{array}{c}12 \\
(2.1-29)\end{array}$ & $\begin{array}{c}2.7^{\mathrm{d}} \\
(1.0-4.4)\end{array}$ & $\begin{array}{c}1.9^{\mathrm{d}} \\
(0.3-3.4)\end{array}$ & $\begin{array}{c}11 \\
(4.1-25)\end{array}$ & $\begin{array}{c}67 \\
(22-153)\end{array}$ & $\begin{array}{c}1.0^{\mathrm{b}} \\
(1.0-1.0)\end{array}$ & $\begin{array}{c}1.7 \\
(1.3-2.0)\end{array}$ \\
\hline Saône & $\begin{array}{c}\text { Downstream } \\
2(200 \mathrm{~m})\end{array}$ & NA & NA & NA & NA & NA & NA & NA & NA & NA & NA & $\begin{array}{c}1.6 \\
(1.0-1.9)\end{array}$ \\
\hline
\end{tabular}

20 a quantification frequency of $25 \%,{ }^{\mathrm{b}}$ quantification frequency of $33 \%,{ }^{\mathrm{c}}$ quantification frequency of $50 \%$, ${ }^{\mathrm{d}}$ quantification frequency of $66 \%$, (if not specified, 21 quantification frequency of $100 \%)$

22 /: not quantified (LOQ between 0.2 and $1.1 \mathrm{ng} / \mathrm{L}$ depending on the sample and the substance), NA: not analyzed 
Author-produced version of the article published in Environmental Science and Pollution Research (2014), vol. 21, $n^{\circ} 3$, pp. 1708-1722

The original publication is available at http://link.springer.com/, doi:10.1007/s11356-013-2037-7 